\title{
Protective intraoperative ventilation with higher versus lower levels of positive end- expiratory pressure in obese patients (PROBESE): study protocol for a randomized controlled trial
}

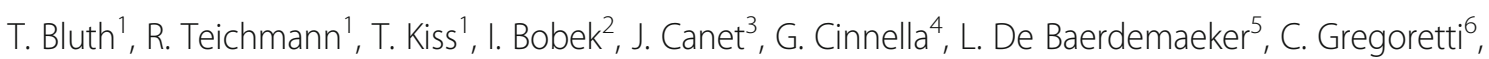
G. Hedenstierna ${ }^{7}$, S. N. Hemmes ${ }^{8,9}$, M. Hiesmayr ${ }^{10,11,12,13}$, M. W. Hollmann ${ }^{8,9}$, S. Jaber ${ }^{14}$, J. G. Laffey ${ }^{15,16,17,18}$, M. J. Licker ${ }^{19}$, K. Markstaller ${ }^{20}$, I. Matot ${ }^{21}$, G. Müller ${ }^{22}$, G. H. Mills ${ }^{23}$, J. P. Mulier ${ }^{24}$, C. Putensen ${ }^{25}$, R. Rossaint ${ }^{26}$, J. Schmitt ${ }^{22}$, M. Senturk ${ }^{27}$, A. Serpa Neto ${ }^{28,29}$, P. Severgnini ${ }^{30}$, J. Sprung ${ }^{31}$, M. F. Vidal Melo ${ }^{32}$, H. Wrigge ${ }^{33}$, M. J. Schultz ${ }^{9,34}$, P. Pelosi ${ }^{35}$, M. Gama de Abreu ${ }^{1 *}$ (D) for the PROBESE investigators, and the PROtective VEntilation Network (PROVEnet) and on behalf of the Clinical Trial Network of the European Society of Anaesthesiology (ESA)

\begin{abstract}
Background: Postoperative pulmonary complications (PPCs) increase the morbidity and mortality of surgery in obese patients. High levels of positive end-expiratory pressure (PEEP) with lung recruitment maneuvers may improve intraoperative respiratory function, but they can also compromise hemodynamics, and the effects on PPCs are uncertain. We hypothesized that intraoperative mechanical ventilation using high PEEP with periodic recruitment maneuvers, as compared with low PEEP without recruitment maneuvers, prevents PPCs in obese patients.

Methods/design: The PRotective Ventilation with Higher versus Lower PEEP during General Anesthesia for Surgery in OBESE Patients (PROBESE) study is a multicenter, two-arm, international randomized controlled trial. In total, 2013 obese patients with body mass index $\geq 35 \mathrm{~kg} / \mathrm{m}^{2}$ scheduled for at least $2 \mathrm{~h}$ of surgery under general anesthesia and at intermediate to high risk for PPCs will be included. Patients are ventilated intraoperatively with a low tidal volume of $7 \mathrm{ml} / \mathrm{kg}$ (predicted body weight) and randomly assigned to PEEP of $12 \mathrm{cmH}_{2} \mathrm{O}$ with lung recruitment maneuvers (high PEEP) or PEEP of $4 \mathrm{cmH}_{2} \mathrm{O}$ without recruitment maneuvers (low PEEP). The occurrence of PPCs will be recorded as collapsed composite of single adverse pulmonary events and represents the primary endpoint.

Discussion: To our knowledge, the PROBESE trial is the first multicenter, international randomized controlled trial to compare the effects of two different levels of intraoperative PEEP during protective low tidal volume ventilation on PPCs in obese patients. The results of the PROBESE trial will support anesthesiologists in their decision to choose a certain PEEP level during general anesthesia for surgery in obese patients in an attempt to prevent PPCs.
\end{abstract}

Trial registration: ClinicalTrials.gov identifier: NCT02148692. Registered on 23 May 2014; last updated 7 June 2016. Keywords: Mechanical ventilation, Positive end-expiratory pressure, Recruitment maneuver, Obesity, Postoperative pulmonary complication

\footnotetext{
* Correspondence: mgabreu@uniklinikum-dresden.de

'Pulmonary Engineering Group, Department of Anesthesiology and Intensive

Care Medicine, University Hospital Carl Gustav Carus, Dresden, Germany

Full list of author information is available at the end of the article
} 


\section{Background}

It is well established that postoperative pulmonary complications (PPCs), especially postoperative respiratory failure, add greatly to perioperative morbidity and mortality, as well as to postoperative length of hospital stay [1-3]. Several independent risk factors for the development of PPCs have been identified, ranging from a patient's health conditions to surgical approaches and anesthetic management [4]. Considering that more than 234 million surgical procedures are performed worldwide per year [5], a reduction of the rate of PPCs might have an important impact on global morbidity and mortality and reduce health system costs. Anesthetists could importantly contribute to preventing such respiratory complications, such as through intraoperative mechanical ventilation strategies expected to affect PPCs beyond preoperative patient status optimization and selection of operative methods to minimize surgical trauma. In fact, mechanical ventilation during general anesthesia has the potential to cause harm to previously noninjured lungs [4].

Authors of an individual patient data meta-analysis showed that intraoperative lung-protective mechanical ventilation using lower tidal volume $\left(\mathrm{V}_{\mathrm{T}}\right)$ in the range of 6 to $8 \mathrm{ml} / \mathrm{kg}$ of predicted body weight (PBW), with or without higher levels of positive end-expiratory pressure (PEEP) and with or without lung recruitment maneuvers (RMs), reduced the incidence of PPCs [2]. More recently, authors of another individual patient data metaanalysis identified the use of intraoperative low $\mathrm{V}_{\mathrm{T}}$ as a protective measure against PPCs, whereas the role of PEEP was unclear [6]. In fact, in a randomized controlled trial with patients with body mass index (BMI) $<40 \mathrm{~kg} / \mathrm{m}^{2}$ undergoing open abdominal surgery, higher PEEP with RMs did not prevent PPCs compared with lower PEEP without RMs [7].

BMI is an important determinant of respiratory function before and during anesthesia in obese patients [810]. In these patients, lung function impairment can manifest as (1) reduced lung volume with increased atelectasis and/or small airway closure; (2) derangements in respiratory system, lung, and chest wall compliance as well as increased resistance; and (3) moderate to severe hypoxemia. These physiological alterations are more marked in obese patients with hypercapnia or obstructive sleep apnea (OSA). To reduce such complications, PEEP levels should theoretically be set higher in obese than in nonobese patients. However, there is as yet no clinical evidence supporting such an approach. An observational study conducted in 28 centers in France revealed that most patients undergoing general surgery, including obese patients, were ventilated with low PEEP $\left(\leq 4 \mathrm{cmH}_{2} \mathrm{O}\right)$ or even without PEEP, even though average PEEP was higher in obese than in nonobese patients
[11]. In fact, current recommendations on the use of PEEP and RMs $[4,12]$ are derived from trials that included mainly patients with BMI $<35 \mathrm{~kg} / \mathrm{m}^{2}$ and therefore cannot be extrapolated to obese patients.

The aim of the PRotective Ventilation with Higher versus Lower PEEP during General Anesthesia for Surgery in OBESE Patients (PROBESE) trial is to compare the effects of two intraoperative mechanical ventilation strategies on PPCs, extrapulmonary postoperative complications (PEPCs), and length of hospital stay, as well as intraoperative lung function and hemodynamics, in surgical patients with BMI $\geq 35 \mathrm{~kg} / \mathrm{m}^{2}$. We hypothesized that intraoperative mechanical ventilation using high PEEP with periodic RMs, as compared with low PEEP without RMs, prevents PPCs in obese patients.

\section{Methods/design}

\section{Objectives and design}

PROBESE is a prospective international multicenter, randomized, controlled, two-arm trial initiated by investigators of the PROtective VEntilation NETwork (www.provenet.eu). In total, 2013 patients will be randomly assigned to one of two different intraoperative mechanical ventilation strategies (see Consolidated Standards of Reporting Trials [CONSORT] diagram, Fig. 1).

The PROBESE trial will test the hypothesis that, during an intraoperative lung-protective mechanical ventilation strategy with low $\mathrm{V}_{\mathrm{T}} \mathrm{s}$, higher levels of PEEP and RMs, as compared with ventilation with lower levels of PEEP without RMs, reduce PPCs in obese patients at intermediate to severe risk for PPCs. After starting the trial, recalculation of the sample size was conducted upon a recommendation of the Data and Safety Monitoring Board (DSMB) (see "Sample size calculations" section). There were changes in neither the study protocol (version 2.5; February 2016, Additional file 1) nor any of the endpoints. A complete checklist of recommended items to address in a clinical trial protocol and related documents according to the "Standard Protocol Items: Recommendations for Interventional Trials (SPIRIT) 2013 is provided in Additional file 2.

\section{Study population}

Investigators screen for obese patients with BMI $\geq 35 \mathrm{~kg} /$ $\mathrm{m}^{2}$ scheduled for surgery under general anesthesia. Patients are eligible if the expected duration of surgery (from incision to closure) exceeds $2 \mathrm{~h}$ and if they are at intermediate to high risk for PPCs. The number of patients meeting these enrollment criteria will be recorded.

To identify patients at risk for PPCs, the Assess Respiratory Risk in Surgical Patients in Catalonia (ARISCAT) score is used [13]. This score predicts individual preoperative risk for PPCs using seven independent predictors, four of which are patient-related and three of which are surgery-related (Table 1). An ARISCAT 


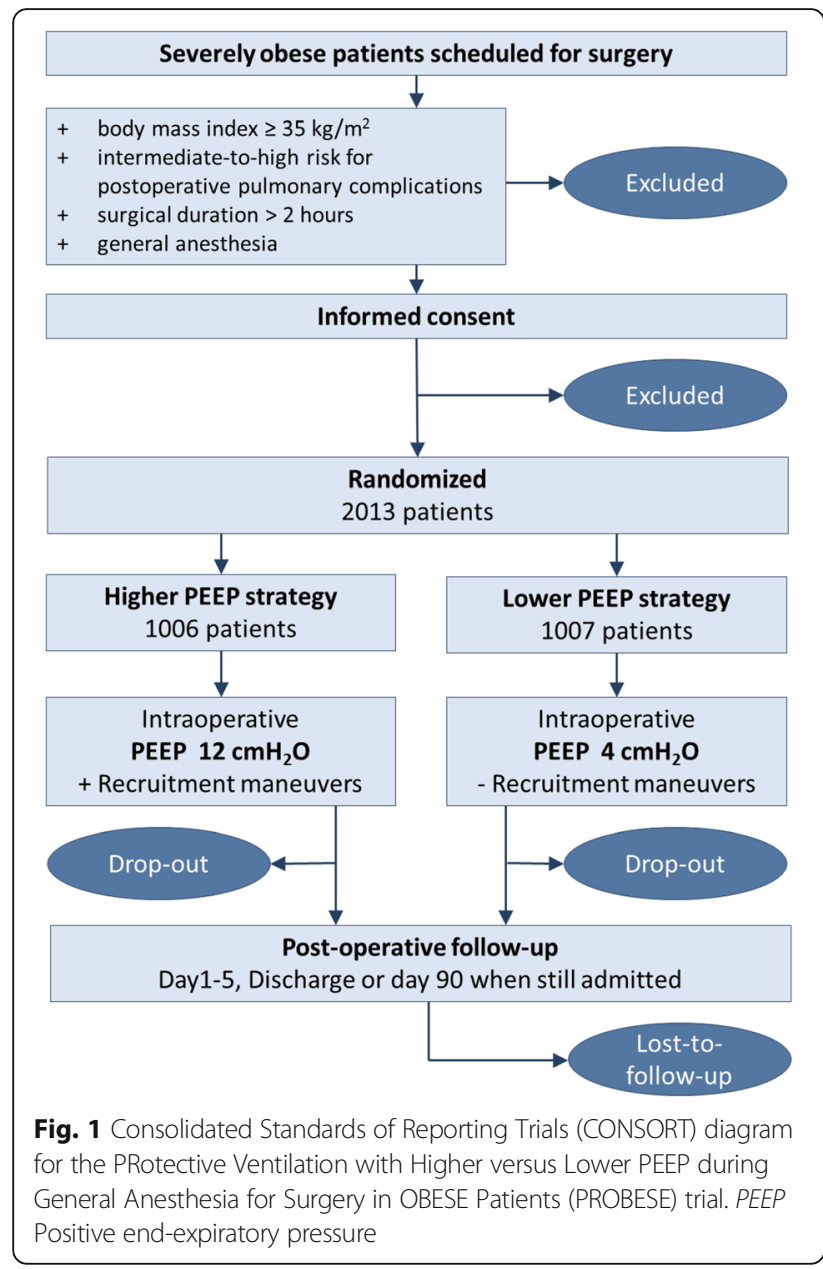

risk score $\geq 26$ is associated with an intermediate to high risk for PPCs.

Patients are excluded from participation if they are aged $<18$ years, have undergone any kind of previous lung surgery, have been invasively mechanically ventilated for longer than 30 minutes within the last 30 days before surgery, or have received recent immunosuppressive medication (chemotherapy or radiation therapy up to 2 months prior to surgery). Further exclusion criteria comprise neurosurgical procedures and cardiac surgery, need for one-lung ventilation or planned reintubation following surgery, need for intraoperative prone or lateral decubitus position, enrollment in another interventional study, or refusal to give written informed consent. Additionally, patients showing at least one the following medical conditions are excluded: pregnancy (excluded by anamnesis and/or laboratory analysis), persistent hemodynamic instability or intractable shock (considered hemodynamically unsuitable for the study by the patient's managing physician), history of severe chronic obstructive pulmonary disease (COPD; defined as noninvasive ventilation and/or oxygen therapy at home or repeated systemic corticosteroid therapy for acute
Table 1 Assess Respiratory Risk in Surgical Patients in Catalonia scores

\begin{tabular}{|c|c|c|c|}
\hline & $\begin{array}{l}\text { Multivariate analysis, } \\
\text { OR }(95 \% \mathrm{Cl}), n=1624\end{array}$ & $\beta$ Coefficient & Risk score \\
\hline \multicolumn{4}{|l|}{ Age, years } \\
\hline$\leq 50$ & 1 & & \\
\hline $51-80$ & $1.4(0.6-3.3)$ & 0.331 & 3 \\
\hline$>80$ & $5.1(1.9-13.3)$ & 1.619 & 16 \\
\hline \multicolumn{4}{|l|}{ Preoperative $\mathrm{SpO}_{2}, \%$} \\
\hline$\geq 96$ & 1 & & \\
\hline $91-95$ & $2.2(1.2-4.2)$ & 0.802 & 8 \\
\hline$\leq 90$ & $10.7(4.1-28.1)$ & 2.375 & 24 \\
\hline $\begin{array}{l}\text { Respiratory infection } \\
\text { in the last month }\end{array}$ & $5.5(2.6-11.5)$ & 1.698 & 17 \\
\hline $\begin{array}{l}\text { Preoperative anemia } \\
(\leq 10 \mathrm{~g} / \mathrm{dl})\end{array}$ & $3.0(1.4-6.5)$ & 1.105 & 11 \\
\hline \multicolumn{4}{|l|}{ Surgical incision } \\
\hline Peripheral & 1 & & \\
\hline Upper abdominal & $4.4(2.3-8.5)$ & 1.480 & 15 \\
\hline Intrathoracic & $11.4(4.9-26.0)$ & 2.431 & 24 \\
\hline \multicolumn{4}{|l|}{ Duration of surgery, $\mathrm{h}$} \\
\hline$\leq 2$ & 1 & & \\
\hline$>2-3$ & $4.9(2.4-10.1)$ & 1.593 & 16 \\
\hline$>3$ & $9.7(4.7-19.9)$ & 2.268 & 23 \\
\hline Emergency procedure & $2.2(1.04-4.5)$ & 0.768 & 8 \\
\hline
\end{tabular}

$\mathrm{SpO}_{2}$ Peripheral oxyhemoglobin saturation measured by pulse oximetry breathing air in supine position

Independent predictors of risk for development of postoperative pulmonary complications as described by Canet et al. [13] (ARISCAT score). A risk score $\geq 26$ predicts an intermediate to high risk for postoperative pulmonary complications)

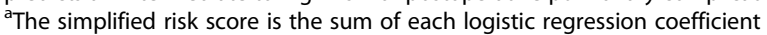
multiplied by 10 , after rounding off its value

exacerbations of COPD), severe cardiac disease (defined as New York Heart Association class III or IV, acute coronary syndrome, or persistent ventricular tachyarrhythmia), concurrent acute respiratory distress syndrome (ARDS) expected to require prolonged postoperative mechanical ventilation, severe pulmonary arterial hypertension (defined as systolic pulmonary arterial pressure $>40 \mathrm{mmHg}$ ), intracranial injury, or tumor or neuromuscular disease.

\section{Intervention}

Patients undergo intraoperative lung-protective mechanical ventilation with protective low $\mathrm{V}_{\mathrm{T}}$ of $7 \mathrm{ml} / \mathrm{kg}(\mathrm{PBW})$, and they are randomly assigned to a PEEP level of $12 \mathrm{cmH}_{2} \mathrm{O}$ with planned lung RMs performed after intubation, hourly thereafter and preceding extubation ("high PEEP"), or a level of PEEP of $4 \mathrm{cmH}_{2} \mathrm{O}$ without planned RMs ("low PEEP"). PEEP levels are to be maintained throughout the whole period of intraoperative mechanical ventilation. 


\section{Minimization of bias}

The allocation sequence is computer-generated (nQuery 4; Statsols, Boston, MA, USA) using permuted blocks of different block sizes, with a maximum block size of 8 . Allocation is stratified per center with an allocation ratio of 1:1 for each group. The process of sequence generation and storage is managed by an independent information technology expert not involved in patient care. Randomization is then performed patient-by-patient using a web interface as an integral part of the online case report form (CRF, Additional file 3; see "Handling of data" section).

At each study site, at least two investigators are involved with the study. One investigator is involved with the intraoperative mechanical ventilation strategy and performs the interventions defined in the protocol. A second investigator, who is blinded to randomization, performs postoperative visits and assessment of primary and secondary endpoints.

\section{Standard procedures}

To avoid interference with the trial intervention, routine elements of perioperative anesthetic care (including general anesthesia, postoperative pain management, physiotherapeutic procedures, and fluid management) are performed according to each center's specific expertise and clinical routine. The following approaches are suggested (not mandatory) for anesthetic management:

1. Use of inhalational isoflurane, desflurane, or sevoflurane; intravenous propofol, remifentanil, or sufentanil; and cisatracurium, atracurium, vecuronium, or rocuronium as required;

2. Use of a balanced solution of prostigmine, or neostigmine and atropine or glycopyrrolate, for reversal of muscle relaxation, guided by neuromuscular function monitoring;

3. Performing postoperative pain management to achieve a visual analogue scale (VAS) pain score $<3$, and regional or neuraxial analgesia should be used whenever indicated;

4. Use of physiotherapy by early mobilization, deep breathing exercises with and without incentive spirometry, and stimulation of cough in the postoperative period; (5) avoidance of hypo- and hypervolemia;

5. Use of invasive measurement of arterial blood pressure whenever indicated; and

6. Use of appropriate prophylactic antibiotic drugs whenever indicated.

Data on the procedures applied will be collected in detail and analyzed.

In addition, the study protocol stresses that routine intraoperative monitoring should include measurements of noninvasive blood pressure, pulse oximetry, end-tidal carbon dioxide fraction, and electrocardiography. Every patient should receive at least one peripheral venous line to allow adequate fluid resuscitation during the study period. Nasogastric tubes, urinary bladder catheters, and/or other intravenous catheters, as well as other, more invasive monitoring, may be used according to local practice and/or guidelines. Other procedures should follow the Safe Surgery Checklist of the World Health Organization (WHO) (www.who.int/patientsafety/ safesurgery/en/index.html).

\section{Mechanical ventilation}

Mechanical ventilation is performed with anesthesia ventilators in use at each individual center participating in the study. Patients undergo volume-controlled mechanical ventilation with the lowest possible fraction of inspired oxygen $\left(\mathrm{FiO}_{2} ; \geq 0.4\right)$ to maintain a peripheral oxyhemoglobin saturation measured by pulse oximetry $\left(\mathrm{SpO}_{2}\right)>92 \%$, an inspiratory-to-expiratory ratio (I:E) of $1: 2$, and a respiratory rate adjusted to normocapnia (end-tidal carbon dioxide partial pressure between 35 and $45 \mathrm{mmHg}$ ). It is left to the discretion of the attending anesthesiologist whether to use a higher $\mathrm{FiO}_{2}$.

$\mathrm{V}_{\mathrm{T}}$ is set to $7 \mathrm{ml} / \mathrm{kg}(\mathrm{PBW})$. The PBW is calculated according to a predefined formula: $50+0.91 \times($ centimeters of height - 152.4) for men and $45.5+0.91 \times$ (centimeters of height-152.4) for women $[14,15] . \mathrm{V}_{\mathrm{T}}$ throughout this protocol refers to the actual inspired $\mathrm{V}_{\mathrm{T}}$ in the ventilator circuit. PEEP is set according to the randomized intervention to 4 vs. $12 \mathrm{cmH}_{2} \mathrm{O}$ and is modified only as part of the rescue strategy (in case of desaturation; see below) or at the discretion of the treating physician.

\section{Planned and unplanned recruitment maneuvers}

The RM, as part of the high-PEEP strategy, is performed directly after induction of anesthesia, after any disconnection from the mechanical ventilator, every $1 \mathrm{~h}$ during surgery, and before extubation, in a hemodynamically stable situation as judged by the anesthesiologist. RMs may also be performed as part of a rescue strategy in the low-PEEP group. To obtain standardization among centers, RMs will be performed in volume-controlled ventilation mode, as shown schematically in Fig. 2, and according to the following steps:

1. Set peak inspiratory pressure limit to $55 \mathrm{cmH}_{2} \mathrm{O}$.

2. Set $\mathrm{V}_{\mathrm{T}}$ to $7 \mathrm{ml} / \mathrm{kg} \mathrm{PBW}$ and respiratory rate to $\geq 6$ breaths/minute while PEEP is $12 \mathrm{cmH}_{2} \mathrm{O}$ (or higher if during rescue; see below).

3. Set I:E to $1: 1$.

4. Increase $\mathrm{V}_{\mathrm{T}}$ in steps of $4 \mathrm{ml} / \mathrm{kg} \mathrm{PBW}$ until plateau pressure reaches $40-50 \mathrm{CmH}_{2} \mathrm{O}$. 


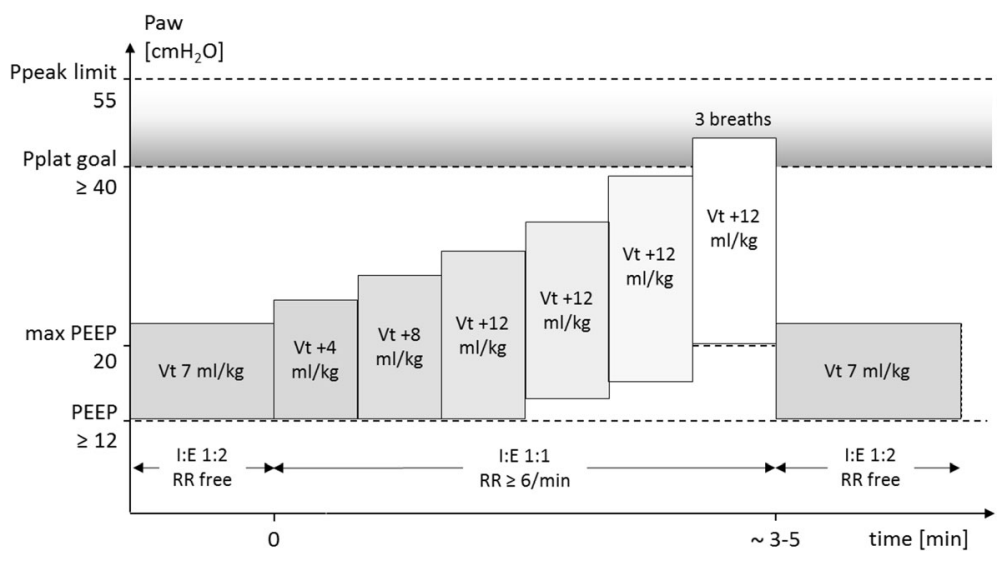

Fig. 2 Lung recruitment maneuver protocol. Ppeak Peak airway pressure, Pplat Plateau airway pressure, PEEP Positive end-expiratory pressure, Vt Tidal volume normalized for predicted body weight, RR Respiratory rate, l:E Ratio between inspiratory and expiratory time

5. If the maximum $\mathrm{V}_{\mathrm{T}}$ allowed by the anesthesia ventilator is achieved and the plateau pressure is $<40 \mathrm{cmH}_{2} \mathrm{O}$, increase the PEEP as needed but only to a maximum of $20 \mathrm{cmH}_{2} \mathrm{O}$.

6. Allow the patient three breaths while maintaining plateau pressure of $40-50 \mathrm{cmH}_{2} \mathrm{O}$.

7. Set respiratory rate, I:E, inspiratory pause, and $V_{T}$ back to prerecruitment values while maintaining PEEP at $12 \mathrm{cmH}_{2} \mathrm{O}$ (or higher if during rescue).

\section{Rescue strategies for intraoperative hypoxemia}

If $\mathrm{SpO}_{2} \leq 92 \%$ develops, increase in airway resistance, presence of intrinsic PEEP, hemodynamic impairment, and ventilator malfunction must be excluded before group-specific stepwise rescue strategies can be applied (Table 2).

In patients receiving lower PEEP levels, rescue consists primarily of an increase in $\mathrm{FiO}_{2}$, whereas elevation of

Table 2 Rescue strategies for intraoperative hypoxemia

\begin{tabular}{|c|c|c|c|c|c|}
\hline \multirow{3}{*}{$\frac{\text { Step }}{1}$} & \multicolumn{2}{|c|}{ Lower PEEP } & \multicolumn{3}{|c|}{ Higher PEEP } \\
\hline & \multirow{2}{*}{$\frac{\mathrm{FiO}_{2}}{0.5}$} & PEEP $\left(\mathrm{cmH}_{2} \mathrm{O}\right)$ & \multirow{2}{*}{$\frac{\mathrm{FiO}_{2}}{0.4}$} & \multicolumn{2}{|c|}{ PEEP $\left(\mathrm{cmH}_{2} \mathrm{O}\right)$} \\
\hline & & 4 & & 14 & (+RM) \\
\hline 2 & 0.6 & 4 & 0.4 & 16 & $(+\mathrm{RM})$ \\
\hline 3 & 0.7 & 4 & 0.4 & 18 & $(+\mathrm{RM})$ \\
\hline 4 & 0.8 & 4 & 0.5 & 18 & \\
\hline 5 & 0.9 & 4 & 0.6 & 18 & \\
\hline 6 & 1.0 & 4 & 0.7 & 18 & \\
\hline 7 & 1.0 & 5 & 0.8 & 18 & \\
\hline 8 & 1.0 & 6 & 0.9 & 18 & \\
\hline 9 & 1.0 & $(+\mathrm{RM})$ & 1.0 & 18 & \\
\hline 10 & & & 1.0 & 20 & $(+\mathrm{RM})$ \\
\hline
\end{tabular}

Abbreviations: $\mathrm{FiO}_{2}$ Fraction of inspired oxygen, PEEP Positive end-expiratory pressure, $R M$ Recruitment maneuver

If intraoperative hypoxemia, defined as oxygen saturation $\leq 92 \%$, develops, sequences of interventions will be used according to group assignment
PEEP levels is restricted to more severe cases of hypoxemia. In the higher PEEP group, the rescue strategy consists primarily of increase of PEEP before $\mathrm{FiO}_{2}$ is to be increased. At any rescue step, the treating physician may consider reducing PEEP if $\mathrm{SpO}_{2}$ deteriorates further in an otherwise hemodynamically stable patient.

\section{Protocol deviation}

Anesthesiologists may deviate from the ventilation protocol at any time if concerns about patient safety arise or upon the surgeon's request. PEEP may be modified according to the anesthesiologist's judgment in the presence of any of the following clinical situations:

1. Decrease in systolic arterial pressure $<90 \mathrm{mmHg}$ and unresponsive to fluids and/or vasoactive drugs

2. Need for a dosage of vasoactive drugs at the tolerance limit

3. New arrhythmias unresponsive to the treatment suggested by the Advanced Cardiac Life Support Guidelines [16]

4. Blood loss requiring massive transfusion (defined as replacement of $>100 \%$ blood volume in $24 \mathrm{~h}$ or $>50 \%$ of blood volume in $4 \mathrm{~h}$ to maintain hematocrit $>21 \%$ [hemoglobin $>7 \mathrm{mg} / \mathrm{dl}]$ )

5. Any life-threatening surgical complication that might benefit from changes in PEEP

Details about any protocol deviation will be prospectively collected and analyzed.

\section{Study endpoints}

The primary endpoint of PROBESE is a collapsed composite of all PPCs developing within the first 5 postoperative days. With this approach, each complication is weighted equally. Patients who develop a least one complication are considered as meeting the primary endpoint. 
PPCs are defined as follows:

1. Mild respiratory failure (partial pressure of arterial oxygen $\left[\mathrm{PaO}_{2}\right]<60 \mathrm{mmHg}$ or $\mathrm{SpO}_{2}<90 \%$ breathing at least 10 minutes of room air but responding to supplemental oxygen of $2 \mathrm{~L} /$ minute, excluding hypoventilation);

2. Moderate respiratory failure $\left(\mathrm{PaO}_{2}<60 \mathrm{mmHg}\right.$ or $\mathrm{SpO}_{2}<90 \%$ breathing $\geq 10$ minutes of room air but responding only to supplemental oxygen $>2 \mathrm{~L} /$ minute, excluding hypoventilation);

3. Severe respiratory failure (need for noninvasive or invasive mechanical ventilation, excluding hypoventilation resulting from use of sedative agents);

4. ARDS (according to the Berlin Definition [17]);

5. Bronchospasm (newly detected expiratory wheezing treated with bronchodilators);

6. New pulmonary infiltrates (chest $x$-ray demonstrating new monolateral or bilateral infiltrate without other clinical signs);

7. Pulmonary infection (new or progressive radiographic infiltrate plus at least two of the following: antibiotic treatment, tympanic temperature $>38^{\circ} \mathrm{C}$, leukocytosis or leukopenia [white blood cell count $<4000$ cells $/ \mathrm{mm}^{3}$ or $>12,000$ cells $\left./ \mathrm{mm}^{3}\right]$, and/or purulent secretions);

8. Aspiration pneumonitis (respiratory failure after the inhalation of regurgitated gastric contents);

9. Pleural effusion (chest $\mathrm{x}$-ray demonstrating blunting of the costophrenic angle, loss of the sharp silhouette of the ipsilateral hemidiaphragm in upright position, evidence of displacement of adjacent anatomical structures, or [in supine position] a hazy opacity in one hemithorax with preserved vascular shadows);

10.Atelectasis (lung opacification with shift of the mediastinum, hilum, or hemidiaphragm toward the affected area, as well as compensatory overinflation in the adjacent nonatelectatic lung);

11.Cardiopulmonary edema (clinical signs of congestion, including dyspnea, edema, rales, and jugular venous distention, with chest $\mathrm{x}$-ray demonstrating increase in vascular markings and diffuse alveolar interstitial infiltrates); and

12.Pneumothorax (air in the pleural space with no vascular bed surrounding the visceral pleura).

Secondary clinical endpoints include the following:

1. Collapsed severe PPC composite, defined as any of the above-mentioned adverse pulmonary events, except mild respiratory failure;

2. Intraoperative adverse events (AEs), such as hypoxemia (defined as $\mathrm{SpO}_{2} \leq 92 \%$ ), hypotension (defined as systolic blood pressure $<90 \mathrm{mmHg}$ ), and bradycardia (defined as heart rate $<50$ beats/minute);
3. Unexpected need for intensive care unit (ICU) admission or ICU readmission;

4. Hospital-free days at follow-up day 90;

5. Postoperative wound healing; and

6. Postoperative extrapulmonary complications (PEPCs).

PEPCs include systemic inflammatory response syndrome, sepsis, severe sepsis, and septic shock (all according to consensus criteria [18]); extrapulmonary infection (wound infection or any other infection); coma (Glasgow Coma Scale score $<8$ in the absence of therapeutic coma or sedation); acute myocardial infarction (according to universal definition of myocardial infarction [19]); acute renal failure (according to the risk, injury, failure, loss, end-stage kidney disease [RIFLE] classification system [20]); disseminated intravascular coagulation (DIC) (according to the International Society of Thrombosis and Hemostasis diagnostic scoring system for DIC [21]); gastrointestinal failure (GIF) (defined according to the GIF score [22]); and hepatic failure (defined as the ratio of total bilirubin on postoperative day 5 to postoperative day $1>1.7$ and ratio of international normalized ratio [INR] on postoperative day 5 to postoperative day $1>1.0$, or new presence of hepatic encephalopathy and coagulopathy [INR >1.5] within 8 weeks after initial signs of liver injury [e.g., jaundice] without evidence of chronic liver disease) (adapted from Du et al. [23] and Wlodzimirow et al. [24]).

At the discretion of participating centers, blood and urine samples are collected preoperatively as well as directly postoperatively and on postoperative day 5 . Samples will be analyzed centrally for systemic markers of inflammation and coagulation (including but not limited to interleukins 6 and 8, thrombin-antithrombin, protein $\mathrm{C}$, and plasminogen activator inhibitor-1) as well as systemic markers of injury to the lungs (including but not limited to plasma E-cadherin, soluble receptor for advanced glycation end products, and surfactant proteins $A$ and D) and to distal organs, including renal injury (including but not limited to plasma/urine neutrophil gelatinase-associated lipocalin and cystatin C). The standard operating procedure for collecting and processing biomarkers in plasma and urine is available in the online supplement (Additional files 4 and 5, respectively).

\section{Study visits and data collection}

Patients are visited preoperatively, intraoperatively, daily between postoperative days 1 and 5 , and at discharge. On postoperative day 90, patients are contacted by phone (Fig. 3). A complete participant time line, including all variables as well as interventions, is available in Additional files 1 and 2.

During the preoperative visit, eligible patients meeting none of the exclusion criteria are asked by physicians to 


\begin{tabular}{|c|c|c|c|c|c|c|c|c|c|c|c|}
\hline \multirow[b]{3}{*}{ TIMEPOINT** } & \multirow{3}{*}{$\begin{array}{c}\text { Enrolment } \\
\begin{array}{c}\text { Preoperative } \\
\text { visit }\end{array}\end{array}$} & \multicolumn{10}{|c|}{ STUDY PERIOD } \\
\hline & & \multicolumn{3}{|c|}{ Allocation / Intervention } & \multicolumn{6}{|c|}{ Post-Intervention } & \multirow{2}{*}{\begin{tabular}{|c|}
$\begin{array}{l}\text { Close- } \\
\text { out }\end{array}$ \\
$\begin{array}{c}\text { POD } 90 \\
\text { (phone } \\
\text { call) }\end{array}$ \\
\end{tabular}} \\
\hline & & $\begin{array}{c}\text { Before } \\
\text { anesthesia }\end{array}$ & $\begin{array}{l}\text { During } \\
\text { surgery } \\
\text { (every } \\
\text { hour) }\end{array}$ & $\begin{array}{l}\text { End of } \\
\text { surgery }\end{array}$ & $\begin{array}{c}\mathrm{POD} \\
1\end{array}$ & $\begin{array}{c}\mathrm{POD} \\
2\end{array}$ & $\begin{array}{c}\mathrm{POD} \\
3\end{array}$ & $\begin{array}{l}\mathrm{POD} \\
4\end{array}$ & $\begin{array}{c}\mathrm{POD} \\
5\end{array}$ & $\begin{array}{c}\text { Hospital } \\
\text { discharge }\end{array}$ & \\
\hline $\begin{array}{l}\text { ENROLMENT } \\
\text { Eligibility screen }\end{array}$ & $\mathrm{X}$ & & & & & & & & & & \\
\hline Informed consent & $\mathrm{X}$ & & & & & & & & & & \\
\hline Demographic data & $X$ & & & & & & & & & & \\
\hline $\begin{array}{c}\text { History of previous } \\
\text { disease }\end{array}$ & $X$ & & & & & & & & & & \\
\hline Allocation & & $\mathrm{X}$ & & & & & & & & & \\
\hline $\begin{array}{r}\text { INTERVENTION } \\
\text { High PEEP with } \\
\text { RM }\end{array}$ & & & $\mathrm{X}$ & & & & & & & & \\
\hline $\begin{array}{l}\text { Low PEEP without } \\
\text { RM }\end{array}$ & & & $\mathrm{X}$ & & & & & & & & \\
\hline $\begin{array}{r}\text { Respiritatory } \\
\text { hemodynamic } \\
\text { variables }\end{array}$ & & & $\mathrm{X}$ & & & & & & & & \\
\hline Adverse events & & & $\mathrm{X}$ & & & & & & & & \\
\hline $\begin{array}{r}\text { Anesthesia/ } \\
\text { Surgery variables }\end{array}$ & & & & $\mathrm{X}$ & & & & & & & \\
\hline $\begin{array}{l}\text { Need for Rescue / } \\
\text { protocol deviation }\end{array}$ & & & & $\mathrm{X}$ & & & & & & & \\
\hline $\begin{array}{l}\text { ASSESSMENTS } \\
\text { Recovery status }\end{array}$ & & & & & $\mathrm{X}$ & $\mathrm{X}$ & $\mathrm{X}$ & $\mathrm{X}$ & $\mathrm{X}$ & $\mathrm{X}$ & \\
\hline $\mathrm{SpO}_{2}$ in room air & $\mathrm{X}$ & & & & $\mathrm{X}$ & $\mathrm{X}$ & $\mathrm{X}$ & $\mathrm{X}$ & $\mathrm{X}$ & $\mathrm{X}$ & \\
\hline $\begin{array}{l}\text { Spirometry / Chest } \\
\text { X-ray (facultative) }\end{array}$ & $\mathrm{X}$ & & & & $\mathrm{X}$ & $\mathrm{X}$ & $\mathrm{X}$ & $\mathrm{X}$ & $\mathrm{X}$ & $\mathrm{X}$ & \\
\hline $\begin{array}{r}\text { Pulmonary } \\
\text { complications }\end{array}$ & & & & & $\mathrm{X}$ & $\mathrm{X}$ & $\mathrm{X}$ & $\mathrm{X}$ & $\mathrm{X}$ & $\mathrm{X}$ & \\
\hline $\begin{array}{l}\text { Extrapulmonary } \\
\text { complications }\end{array}$ & & & & & $x$ & $x$ & $x$ & $x$ & $x$ & $x$ & \\
\hline Adverse events & & & & & $\mathrm{X}$ & $\mathrm{X}$ & $\mathrm{X}$ & $\mathrm{X}$ & $\mathrm{X}$ & $\mathrm{X}$ & \\
\hline $\begin{array}{r}\text { Blood sampling } \\
\text { (special markers, } \\
\text { facultative) }\end{array}$ & & $\mathrm{X}$ & & $\mathrm{x}$ & & & & & $x$ & & \\
\hline$P O D$ of discharge & & & & & & & & & & $\mathrm{X}$ & \\
\hline $\begin{array}{l}\text { Hospital free days } \\
\text { on POD } 90\end{array}$ & & & & & & & & & & & $\mathrm{X}$ \\
\hline
\end{tabular}

Fig. 3 Schedule of enrollment, interventions, and assessments. POD Postoperative day, PEEP Positive end-expiratory airway pressure, RM Recruitment maneuver, $\mathrm{SpO}_{2}$ Peripheral oxyhemoglobin saturation measured by pulse oximetry

provide written informed consent. (Model consent form and information to study patients). Baseline variables are collected, including sex; age; height; weight; BMI; waist/ hip ratio according to WHO guidelines; physical status according to the American Society of Anesthesiologists; functional status according to Cumulated Ambulation Score [25]; cardiovascular status (heart failure according to the New York Heart Association classification, coronary heart disease according to Canadian Cardiovascular Society, atrial flutter/fibrillation, arterial hypertension); pulmonary status (COPD, including steroids and/or inhalation therapy use, respiratory infection within the last month, use of noninvasive ventilatory support); history of OSA, including apnea-hypopnea index or STOP-Bang score (snoring, tired, observed stopped breathing or choking/gasping, pressure, body mass index $>35 \mathrm{~kg} / \mathrm{m}^{2}$, age $>50$ years, large neck size, and male sex) [26] in patients without diagnosis of OSA); metabolic status (diabetes mellitus, including data on treatment); history of active cancer; smoking status; alcohol status; gastroesophageal reflux; oral medication (e.g., use of antibiotics, statins, aspirin); preoperative organ function $\left(\mathrm{SpO}_{2}\right.$ in beach chair position breathing room air; if possible, $\mathrm{SpO}_{2}$ in supine position breathing room air; if possible, so-called oxygen stress test, with this measurement left to the discretion of each center); respiratory rate; heart rate; mean arterial pressure; body temperature; airway secretion, including data on purulence, VAS score (1-10) for dyspnea, chest pain, and abdominal rest; and incident pain. Preoperative nonmandatory measurements include spirometry (forced ventilatory capacity, forced expiratory volume in 1 second), chest $x$-ray (assessed for infiltrates, pleural effusion, atelectasis, pneumothorax, and cardiopulmonary edema), and routine 
laboratory tests (including hemoglobin, white blood cell count, platelet count, prothrombin time, partial thromboplastin time, creatinine, blood urea nitrogen, alanine aminotransferase, aspartate amino transferase, bilirubin).

During the intraoperative visit, both surgery- and anesthesia-related data are recorded, including duration of surgery (from incision to closure), transfusion of blood products within $6 \mathrm{~h}$ before surgery, priority and type of surgery, wound classification, patient positioning during operation, duration of anesthesia (from intubation to extubation or exit from operating room if on mechanical ventilation), anesthetic procedure details, drugs and fluids administered during anesthesia (e.g., anesthetics, vasoactive drugs, transfusion). Ventilator settings, hemodynamics, need for rescue strategy, and AEs are recorded at anesthesia induction and hourly thereafter (in the higher PEEP group, before performing the $\mathrm{RM}$ ) as well as during the plateau phase of the RM.

Clinical data, including actual organ function and the presence of PPCs and PEPCs, are scored during postoperative visits on a daily basis. Nonmandatory measures include chest $\mathrm{x}$-ray, spirometry, and routine laboratory tests. Patients will be visited until discharge. On postoperative day 90, the sum of hospital-free days is recorded. Day 90 is defined as the last day of follow-up; accordingly, patients still admitted to the hospital will be last visited on that day.

\section{Study dropouts}

Because participation in the trial is voluntary, a subject has the right to withdraw consent to participate in the study at any time for any reason without any consequences for further medical treatment. Furthermore, investigators have the right to terminate participation of any subject at any time if the investigator deems it in the participant's best interest. The reasons and circumstances for study discontinuation will be documented in the CRF. Primarily, all data will be analyzed according to the intention-to-treat (ITT) principle. Secondarily, data will be analyzed as per protocol.

\section{Handling of data}

Patient data are collected in pseudonymous form using a patient identification number of six digits. The first three digits correspond to the site identifier, and the remaining three digits correspond to the patient inclusion number at the respective site. Study data are collected and managed using Research Electronic Data Capture (REDCap ${ }^{\mathrm{Tw}}$; a web-based system used during PROBESE as electronic case report form) electronic data capture tools hosted at the Coordinating Center for Clinical Trials of the University of Dresden, Germany [27]. REDCap is a Secure Sockets Layer (SSL)-encrypted, password-protected, web-based application designed to support data capture for research studies. Full access to the final trial dataset will be granted to selected investigators only (MGdA, $\mathrm{TB}$, and $\mathrm{JSc}$ ). If a substudy is approved by the steering committee, access to data related only to the substudy will be granted to the respective principal investigator.

\section{Sample size calculations}

Sample size calculation was based on our primary hypothesis that, in obese patients ventilated intraoperatively with protective low $\mathrm{V}_{\mathrm{T}}$, high PEEP leads to lower incidence of PPCs than lower PEEP. Effect sizes were derived from data collected during the ARISCAT study [13] and a single-center, relatively small study in which researchers reported the effects of intraoperative higher PEEP and RMs on the incidence of postoperative desaturation, chest infection, and bronchospasm in obese patients who underwent laparoscopic bariatric surgery [28].

Prior to the start of the study, these calculations had indicated that 356 patients would be required per group, assuming a two-sided significance level of $0.05(\alpha)$ and a power of $80 \%$, to detect the expected difference in PPCs between the higher-PEEP group of $30 \%$ and the lowerPEEP group of $40 \%$ (risk ratio of 0.75 ). However, the sample size was reestimated after data of the first 618 patients revealed that the overall incidence of the collapsed composite outcome was $20 \%$ and, thus, lower than initially expected. Also, the adjustment of the sample size took into account the need for interim analyses for efficacy and futility at $50 \%, 75 \%$, and $100 \%$ of the total number of patients, for which a nonbinding group sequential design with $\gamma$ spending functions $(\gamma=-4$ for each of $\alpha$ and $\beta$ ) was used. In total, 1912 patients will be included in the analysis. Assuming a dropout rate of 5\%, 2013 patients will be enrolled. Table 3 shows the $\alpha$ and $\beta$ spent over the trial, $\mathrm{z}$-statistic boundaries for efficacy and futility, and boundary-crossing probabilities under the alternative hypothesis (H1). The corresponding $P$ value boundaries for efficacy and futility at the first, second, and final looks, respectively, are $P \leq 0.006, P \leq 0.015$, and $P \leq 0.044$, as well as $P>0.82$, $P>0.35$, and $P>0.044$, respectively. Figure 4 displays the z-statistic boundaries for efficacy/harm and futility as a function of accrued sample size. East 6.0 interim monitoring software (Cytel Inc., Cambridge, MA, USA) was used for sample size calculations.

To foster the study and increase the interest of practicing physicians, the steering committee will apply for endorsement of national and international professional societies. The following societies have already given endorsement to the trial: the European Society of Anaesthesiology, the European Society for Perioperative Care of the Obese Patient, the German Society of Anesthesiology and Intensive Care Medicine, and the Italian Society of Anesthesiology and Reanimation. 
Table 3 Z-statistic boundaries and boundary-crossing probabilities

\begin{tabular}{|c|c|c|c|c|c|c|c|c|}
\hline \multirow[t]{2}{*}{ Look } & \multirow{2}{*}{$\begin{array}{l}\text { Information } \\
\text { fraction }\end{array}$} & \multirow[t]{2}{*}{$N$} & \multirow{2}{*}{$\begin{array}{l}\text { Cumulative } \\
\text { a spent }\end{array}$} & \multirow{2}{*}{$\begin{array}{l}\text { Cumulative } \\
\beta \text { spent }\end{array}$} & \multirow{2}{*}{$\begin{array}{l}\text { Z- } \\
\text { efficacy }\end{array}$} & \multirow{2}{*}{$\begin{array}{l}\text { Z- } \\
\text { futility }\end{array}$} & \multicolumn{2}{|c|}{ Boundary-crossing probabilities under $\mathrm{H} 1$} \\
\hline & & & & & & & Efficacy & Futility \\
\hline 1 & 0.5 & 956 & 0.006 & 0.024 & $\geq 2.75$ & $<0.225$ & 0.234 & 0.024 \\
\hline 2 & 0.75 & 1434 & 0.018 & 0.071 & $\geq 2.432$ & $<0.929$ & 0.296 & 0.047 \\
\hline 3 & 1 & 1912 & 0.05 & 0.2 & $\geq 2.012$ & $<2.012$ & 0.271 & 0.129 \\
\hline
\end{tabular}

Look Interim analysis, $N$ Number of patients, $H 1$ Hypothesis 1 (group difference exists)

Values were calculated using power $=0.80, a=0.05, \gamma$ spending functions $(\gamma=-4)$, and expected incidence of postoperative pulmonary complications of $20 \%$ ( 1 ) and $15 \%(\mathrm{p} 2)$ in the lower and higher positive end-expiratory pressure groups, respectively

\section{Statistical analysis}

Exploratory analysis will include mean and SD for normally distributed variables. Non-normally distributed variables will be expressed by their medians and IQRs, and categorical variables will be expressed as count (percent). Parametric or nonparametric tests will be used as appropriate. Categorical variables will be compared with chi-square tests, Fisher's exact test, or as relative risk, if appropriate. Statistical uncertainty will be expressed by $95 \%$ CIs.

Preoperative (baseline) data will be tested for any imbalance. If imbalances are detected (despite 1:1 randomization of a relatively large cohort), those factors will be corrected for using a multiple logistic regression model.

The primary endpoint, namely occurrence of any PPC (collapsed composite endpoint) within the first 5 postoperative days, will be presented as total percentage per group and analyzed as continuous data. Primary and secondary outcome variables describing time to event will be analyzed using a proportional hazards model adjusted for possible baseline imbalances. A linear mixed model with two factors (study group and time) will be used to analyze variables repetitively measured over time.

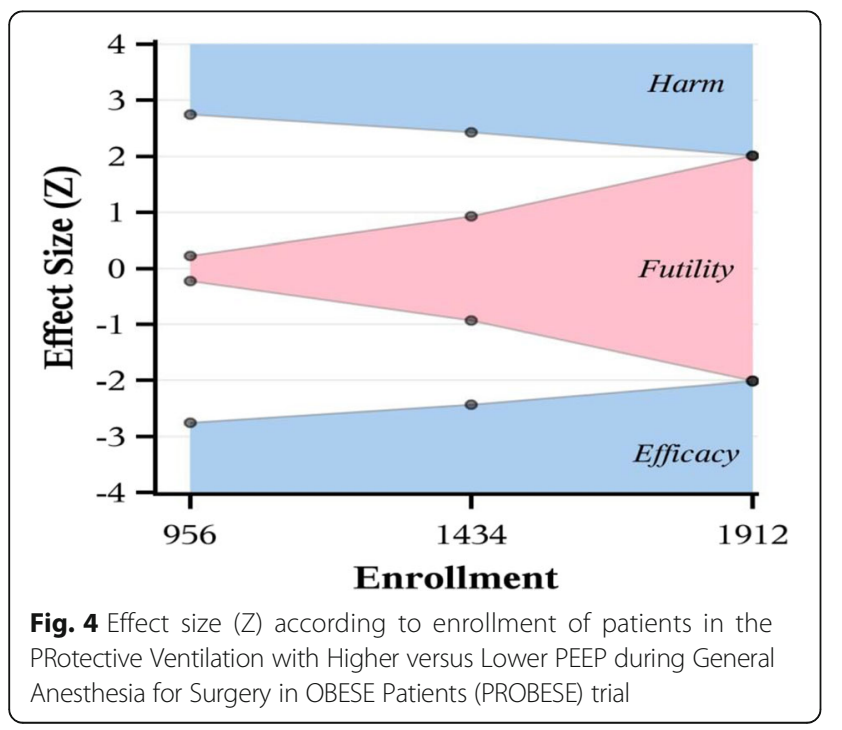

In case of loss to follow-up or study dropout, those cases will be reported, and ITT as well as per-protocol analyses will be performed. For ITT analysis, data will be processed for all patients in the groups to which they were randomized. The per-protocol analysis will be conducted to assess the primary outcome in cases where there is a considerable proportion of patients who do not receive their randomized intervention or are lost to follow-up. Patients discharged earlier than postoperative day 5 are considered as not experiencing any PPC or PEPC during the out-of-hospital days. In this regard, missing data will be handled by means of the last observation carried forward method.

Given that laparoscopic surgery is common in obese patients, we anticipate that a subgroup analysis of primary and secondary endpoints will be conducted for this type of surgery as well. A further subgroup analysis of patients with obesity class III according to the WHO definition (i.e., BMI $\geq 40 \mathrm{~kg} / \mathrm{m}^{2}$ ) will be performed. Given the importance of driving pressure to determine PPCs $[29,30]$, a subgroup analysis taking into account cutoff values and changes in PEEP will be conducted.

\section{Possibility and policy for substudies}

Participating centers are allowed to conduct substudies, provided that (1) no interference with the primary protocol occurs; (2) approval by the local institutional review board is obtained; and (3) the steering committee accepts the proposal according to its originality, feasibility, and importance. Currently, substudies with electrical impedance tomography, spirometry, respiratory system mechanics, and preoperative oxygen stress test are under evaluation. Publication of substudies, in any form, is strictly forbidden until the results of the primary study have been published.

\section{Trial organization}

The trial is managed by a team consisting of the chief investigator (MGdA), the trial coordinator (TB), the statisticians (JSc, GM), the informatics technician responsible for the web-based electronic data capture system (Marko Kaeppler), and the monitors (Luigi Vivona, Alice Bergamaschi). A steering committee contributed to the design and revision 
of the study and will be responsible for interpretation of data and compilation of a resulting manuscript.

Patient data and safety are closely monitored by a DSMB, which is composed of a chairperson (Daniel Sessler) and four other members (Jennifer Hunter, Jeanine Wiener-Kronish, Jean-Louis Vincent, and Andreas Hoeft). All AEs entered into the electronic CRF within prespecified time frames, including severe AEs and suspected unexpected severe adverse reactions, are monitored by an international AE manager (ASN), who provides the DSMB with reports for review. The DSMB further monitors the overall status of the trial (e.g., progress of patient enrollment, general adherence to protocol, and completeness of data entry). Monitoring visits will be conducted as deemed necessary by the DSMB. National coordinators are responsible for administration and communication with local principal investigators, as well as for assistance during trial management and data collection. When submitting the report on the results of the trial for possible publication, sites will be eligible for one collaborative coauthorship plus a further coauthorship for every 12 treated patients with complete datasets.

\section{Discussion}

Despite being lifesaving, mechanical ventilation has the potential to aggravate or even initiate lung injury. In patients with previously injured lungs, especially those with ARDS, mechanical ventilation with low $\mathrm{V}_{\mathrm{T}}$ [31] and driving pressures [32] has been shown to decrease mortality. Furthermore, in more severe ARDS, high PEEP improves survival [33]. Such effects have been attributed to avoidance of tidal overdistention as well as cyclic collapse and reopening of lung units, which may trigger the inflammatory lung response [34]. Interestingly, low $V_{T}$ with low to moderate PEEP levels has been also reported to facilitate weaning [35] and reduce pulmonary complications [36] in critically ill patients without lung injury. However, the value of protective ventilation in the absence of lung injury has been challenged. In pigs with noninjured lungs, $\mathrm{V}_{\mathrm{T}}$ as high as $27 \mathrm{ml} / \mathrm{kg}$ was not associated with relevant degrees of lung damage [37]. Such an observation might be explained by the fact that, within a certain range, mechanical ventilation does not injure lungs if a previous insult (first hit), such as inflammation, ischemia-reperfusion injury, or factors impairing the homogeneity of ventilation [38], are not present. Surgery itself can trigger a systemic inflammatory response [39], which may prime the lungs for possible harmful effects of mechanical ventilation. In fact, protective intraoperative mechanical ventilation with low $\mathrm{V}_{\mathrm{T}}$ and PEEP is able to prevent postoperative respiratory failure in patients undergoing abdominal or thoracic surgery, and those who develop this adverse pulmonary event not only have longer stays in the hospital but also a significantly higher risk of death [2]. However, though the role of intraoperative low $\mathrm{V}_{\mathrm{T}}$ [6] and low driving pressure $[29,30]$ to decrease the risk of PPCs has been defined, the role of PEEP is more controversial $[4,7,40,41]$.

The decision to address the obese patient population undergoing surgery is based on several aspects. The proportion of obese patients undergoing surgery is higher than in the general population [42]. Treatment of these patients is usually challenging because their needs in terms of perioperative care differ from those of nonobese patients and are often unmet. For example, the deleterious effects of anesthesia on the respiratory system of obese patients are exacerbated when compared with nonobese patients. The known decrease in endexpiratory lung volume following induction of general anesthesia is striking in obese patients, mainly because of formation of lung atelectasis, which may impair gas exchange [43]. Previous studies addressed the effects of intraoperative mechanical ventilation strategies aimed at reverting the formation of atelectasis during general anesthesia in obese patients. Respiratory strategies that increase the pressure of the airways during induction of anesthesia, such as the application of noninvasive ventilation [44], use of PEEP with [45] or without RMs [46], or a combination of all of these [47], seem to be useful for improving the respiratory function of obese patients in the pre- and intraoperative periods [48]. Nevertheless, their effects seem to be short-lived in the postoperative period $[49,50]$. To our knowledge, the impact of such strategies on clinically relevant outcome endpoints, such as adverse pulmonary events, has not previously been addressed. Therefore, we believe PROBESE is the first large, international, multicenter randomized controlled trial addressing the effects of PEEP during protective low $\mathrm{V}_{\mathrm{T}}$ on postoperative outcome.

We opted for testing the impact of two ventilation strategies at the same low $\mathrm{V}_{\mathrm{T}}$ but mainly differing in the level of PEEP. The decision to use a PEEP value of 4 $\mathrm{cmH}_{2} \mathrm{O}$ in the low-PEEP group derives mainly from reports on the practice of intraoperative mechanical ventilation in obese patients $[11,51]$, but it also takes into account aspects regarding patient safety. In fact, use of PEEP of $0 \mathrm{cmH}_{2} \mathrm{O}$ during anesthesia in morbidly obese patients is still common practice and is usually compensated for by means of proportionally high $\mathrm{V}_{\mathrm{T}}$ values [52]. The level of PEEP in the high-PEEP group has been intensely debated by the steering committee of the trial. The decision to use a PEEP of $12 \mathrm{cmH}_{2} \mathrm{O}$ was based on reports of several small clinical studies showing that such a level of PEEP is able to preserve the end-expiratory lung volume after induction of anesthesia $[46,53]$ and to avoid development of significant atelectasis when preceded by 
RMs [45]. Theoretically, PEEP values $>12 \mathrm{cmH}_{2} \mathrm{O}$ might be even more effective to avoid progressive derecruitment of lungs, but they could also result in more severe impairment of hemodynamics $[54,55]$. In fact, a previous trial by our group with nonobese patients undergoing open abdominal surgery showed that high PEEP levels are more frequently associated with intraoperative hypotension that in turn requires more fluids and support with vasoactive drugs [7]. We also decided not to use an individual titration of PEEP for two reasons. First, even a PEEP titrated to a respiratory mechanical target, such as the elastance of the respiratory system, represents a compromise in terms of regional overdistention and collapsing-reopening of lung units and does not fully prevent atelectasis formation. Second, the setting of PEEP shall be pragmatic (i.e., practicable for anesthetists worldwide) while keeping the physiological rationale. The RM is based on a stepwise increase of $\mathrm{V}_{\mathrm{T}}$ and PEEP, which allows opening of lung units without interruption of mechanical ventilation [40] and ensures standardization across different centers [7]. Furthermore, because the maneuver was designed for volume-controlled ventilation, it can be performed with practically all anesthesia ventilators. During RMs, the target airway pressure in the range of $40-50 \mathrm{cmH}_{2} \mathrm{O}$ was based on previous functional studies in obese patients. Also, the inspiratory time of approximately 5 seconds was chosen to allow enough pressure versus time product to open atelectatic lung units [56]. We opted for recruiting lungs not only after intubation but also every hour thereafter in order to revert possible progressive derecruitment at PEEP of $12 \mathrm{cmH}_{2} \mathrm{O}$. For both the lower- and higherPEEP groups, rescue protocols for the progression of intraoperative hypoxemia were defined to protect patients while allowing a standardized approach that minimizes interference with the respective interventions. Importantly, deviations from the protocol, even rescue because of hypoxemia, are explicitly allowed, provided this is in the best interest of the patient.

It is worth noting that recommendations have been made also with regard to different phases and aspects of the anesthetic procedure, including monitoring, choice of anesthetic agents, muscle paralysis and its reversal, intravascular volume loading and maintenance, postoperative analgesia target, and respiratory management at induction and emergence of anesthesia (e.g., use of continuous or noninvasive positive pressure and positioning). However, PROBESE is a pragmatic study, and influence on local practice of respective sites is being kept to a minimum, focusing on factors that are more directly related to the hypothesis being investigated.

Besides postoperative respiratory failure, several other adverse pulmonary events seem to add to the odds of mortality in the surgical population. In-hospital length of stay and mortality increase with the number of single pulmonary AEs in the postoperative period [1]. For this reason, in the PROBESE trial, we opted for a binary collapsed composite of single adverse pulmonary events as a primary endpoint, despite the fact that single events may differ in terms of severity. Therefore, the use of PPCs as a primary endpoint in the PROBESE trial not only has clinical relevance for the practicing anesthetist but also increases the study power because of summation of the incidence of single AEs. In spite of this, the study analysis will address not only the composite itself but also the incidence of each element separately, as well as a secondary composite that excludes mild respiratory failure. Furthermore, given the importance of minimally invasive surgical techniques in the obese population, we will conduct a separate analysis of the primary endpoint in patients undergoing laparoscopic surgery, as well as of patients with obesity class III of the WHO (BMI $\geq 40 \mathrm{~kg} / \mathrm{m}^{2}$ ).

Not only the respiratory system but also other organ systems may be impaired in the postoperative period in obese patients. Thus, the analysis will also address the impact of intraoperative mechanical ventilation on single organs and a collapsed composite of nonpulmonary AEs, namely the PEPCs. In addition, further relevant outcome measures that might be related to PPCs and PEPCs, especially the length of hospital stay, will be addressed. This outcome variable not only is a measure of morbidity but has also direct impact on related health costs. Because we anticipate that, during surgery, both the lower- and the higher-PEEP groups will experience impacts on intraoperative oxygenation, respiratory system mechanics, and arterial blood pressure, intraoperative respiratory function and hemodynamic variables will also be evaluated.

Much attention has been paid to safety in the PROBESE trial. Accordingly, data and patient safety during the PROBESE trial is closely monitored by a DSMB whose members have been chosen for their expertise in clinical research, as well as by a serious AE/AE manager. The web-based approach for research electronic data capture $\left(\right.$ REDCap $^{\mathrm{mm}}$ ) will be used for building the database within a secure system and allowing access to the electronic CRF as well as randomization of patients into groups within one single platform from all participating sites across the world.

In summary, PROBESE is the first multicenter, international, adequately powered randomized controlled trial that compares the effects of two different levels of intraoperative PEEP during protective low $\mathrm{V}_{\mathrm{T}}$ on PPCs in obese patients. The results of the PROBESE trial will support anesthesiologists in their decision to set PEEP during general anesthesia for surgery in obese patients.

\section{Trial status}

The PROBESE trial is currently recruiting patients. 


\section{Appendix 1}

Table 4 PROBESE investigators

\begin{tabular}{|c|c|c|c|}
\hline Site ID & Site name & Collaborator(s) & Email address(es) \\
\hline 001 & $\begin{array}{l}\text { Department of Anesthesiology and Intensive } \\
\text { Care Medicine, Pulmonary Engineering Group, } \\
\text { University Hospital Dresden, Germany }\end{array}$ & $\begin{array}{l}\text { Andreas Güldner } \\
\text { Robert Huhle } \\
\text { Christopher Uhlig } \\
\text { Luigi Vivona } \\
\text { Alice Bergamaschi }\end{array}$ & $\begin{array}{l}\text { andreas.güldner@uniklinikum-dresden.de } \\
\text { robert.huhle@tu-dresden.de } \\
\text { christopher.uhlig@uniklinikum-dresden.de } \\
\text { vivonag@tiscali.it } \\
\text { alice_bergamaschi@libero.it }\end{array}$ \\
\hline 002 & $\begin{array}{l}\text { Department of Anesthesiology, University of } \\
\text { Aachen, Germany }\end{array}$ & $\begin{array}{l}\text { Rossaint, Rolf } \\
\text { Stevanovic, Ana }\end{array}$ & $\begin{array}{l}\text { rrossaint@ukaachen.de } \\
\text { astevanovic@ukaachen.de }\end{array}$ \\
\hline 003 & $\begin{array}{l}\text { Department of Anesthesiology CLIPS Clinical } \\
\text { Trials - Patient-centered Studies, University } \\
\text { Hospital Düsseldorf, Germany }\end{array}$ & $\begin{array}{l}\text { Treschan, Tanja } \\
\text { Maximilian Schaefer } \\
\text { Kienbaum, Peter }\end{array}$ & $\begin{array}{l}\text { tanja.treschan@med.uni-duesseldorf.de } \\
\text { maximilian.schaefer@med.uni-duesseldorf.de } \\
\text { peter.kienbaum@med.uni-duesseldorf.de }\end{array}$ \\
\hline 004 & $\begin{array}{l}\text { Department of Anesthesiology, University } \\
\text { Medical Center Mainz, Germany }\end{array}$ & Laufenberg-Feldmann, Rita & rita.laufenberg@unimedizin-mainz.de \\
\hline 005 & $\begin{array}{l}\text { Department of Anesthesiology, Intensive Care } \\
\text { and Pain Medicine, University Clinic } \\
\text { Knappschaftskrankenhaus Bochum, Germany }\end{array}$ & $\begin{array}{l}\text { Bergmann, Lars } \\
\text { Ebner, Felix } \\
\text { Robitzky, Luisa } \\
\text { Mölders, Patrick } \\
\text { Unterberg, Matthias }\end{array}$ & $\begin{array}{l}\text { lars.bergmann@kk-bochum.de } \\
\text { felix.ebner@kk-bochum.de } \\
\text { luisa.robitzky@gmail.com } \\
\text { patrick.moelders@kk-bochum.de } \\
\text { matthias.unterberg@kk-bochum.de }\end{array}$ \\
\hline 006 & $\begin{array}{l}\text { Department of Anesthesiology, University } \\
\text { Hospital Heidelberg, Germany }\end{array}$ & Busch, Cornelius & cornelius.busch@med.uni-heidelberg.de \\
\hline 007 & $\begin{array}{l}\text { Department of Anesthesiology, Marienhospital } \\
\text { Wesel, Germany }\end{array}$ & Achilles, Marc & marc.achilles@prohomine.de \\
\hline 008 & $\begin{array}{l}\text { Department of Anesthesiology and Intensive } \\
\text { Care Medicine, Marienstift Friesoythe, Germany }\end{array}$ & $\begin{array}{l}\text { Menzen, Angelika } \\
\text { Freesemann, Harbert }\end{array}$ & $\begin{array}{l}\text { dr.menzen@marienstift-friesoythe.de } \\
\text { dr.freesemann@smhf.de }\end{array}$ \\
\hline 009 & $\begin{array}{l}\text { Department of Anesthesiology and Intensive } \\
\text { Care Medicine, University Hospital Bonn, Germany }\end{array}$ & Putensen, Christian & putensen@uni-bonn.de \\
\hline 011 & $\begin{array}{l}\text { Serviço de Anestesiologia, Centro Hospitalar } \\
\text { do Porto, Portugal }\end{array}$ & $\begin{array}{l}\text { Machado, Humberto } \\
\text { Cavaleiro, Carla } \\
\text { Ferreira, Cristina } \\
\text { Pinho, Daniela } \\
\text { Carvalho, Marta } \\
\text { Pinho, Sílvia } \\
\text { Soares, Maria }\end{array}$ & $\begin{array}{l}\text { director.anestesia@hgsa.min-saude.pt } \\
\text { cscavaleiro@gmail.com } \\
\text { crispintoferreira@gamil.com } \\
\text { daniepinho@gmail.com } \\
\text { marta.monteiro.carvalho@gmail.com } \\
\text { silviabpinho@gmail.com } \\
\text { mariapereirasoares@gmail.com }\end{array}$ \\
\hline 012 & $\begin{array}{l}\text { Serviço de Anestesiologia, Centro Hospitalar Entre } \\
\text { o Douro e Vouga, Santa Maria da Feira, Portugal }\end{array}$ & Castro, Diogo Sousa & diogosousacastro@hotmail.com \\
\hline 013 & $\begin{array}{l}\text { Serviço de Anestesiologia, Centro Hospitalar São } \\
\text { João, Porto, Portugal }\end{array}$ & Abelha, Fernando & fernando.abelha@gmail.com \\
\hline 014 & $\begin{array}{l}\text { Serviço de Anestesiologia, Hospital Pedro Hispano, } \\
\text { Matosinhos, Portugal }\end{array}$ & Rabico, Rui & rrabico@gmail.com \\
\hline 021 & $\begin{array}{l}\text { Department of Anesthesiology, Montefiore Medical } \\
\text { Center Bronx, New York, NY, USA }\end{array}$ & Delphin, Ellise & edelphin@montefiore.org \\
\hline 022 & $\begin{array}{l}\text { Department of Anesthesiology, Mayo Clinic, } \\
\text { Rochester, MN, USA }\end{array}$ & $\begin{array}{l}\text { Sprung, Juraj } \\
\text { Weingarten, Toby N. } \\
\text { Kellogg, Todd A. } \\
\text { Martin, Yvette N. } \\
\text { McKenzie, Travis J }\end{array}$ & $\begin{array}{l}\text { sprung.juraj@mayo.edu } \\
\text { weingarten.toby@mayo.edu } \\
\text { kellogg.todd@mayo.edu } \\
\text { martin.yvette@mayo.edu } \\
\text { mckenzie.travis@mayo.edu }\end{array}$ \\
\hline 023 & $\begin{array}{l}\text { Department of Anesthesiology, Mayo Clinic, } \\
\text { Jacksonville, FL, USA }\end{array}$ & $\begin{array}{l}\text { Brull, Sorin J. } \\
\text { Renew, J. Ross }\end{array}$ & $\begin{array}{l}\text { brull.sorin@mayo.edu } \\
\text { renew.j@mayo.edu }\end{array}$ \\
\hline 024 & $\begin{array}{l}\text { Department of Anesthesiology, Mayo Clinic, } \\
\text { Phoenix, AZ, USA }\end{array}$ & Ramakrishna, Harish & ramakrishna.harish@mayo.edu \\
\hline 025 & $\begin{array}{l}\text { Department of Anesthesiology, University of } \\
\text { Colorado SOM, Aurora, CO, USA }\end{array}$ & Fernandez-Bustamante, Ana & ana.fernandez-bustamante@ucdenver.edu \\
\hline 026 & $\begin{array}{l}\text { Department of Anesthesiology, Tufts Medical } \\
\text { Center, Boston, MA, USA }\end{array}$ & Balonov, Konstantin & kbalonov@tuftsmedicalcenter.org \\
\hline 027 & $\begin{array}{l}\text { Department of Anesthesiology, University of } \\
\text { Mississippi, Jackson, MS, USA }\end{array}$ & Baig, Harris R. & hbaig@umc.edu \\
\hline
\end{tabular}


Table 4 PROBESE investigators (Continued)

Department of Anesthesiology, University of Chicago, Chicago, IL, USA

Department of Anesthesiology, Pontificia Universidad Católica de Chile, Santiago de Chile, Chile
Department of Intensive Care, Academic Medical Center, University of Amsterdam, The Netherlands

Department of Anesthesiology, Leiden University Medical Center, Leiden, The Netherlands

Department of Anesthesiology, Westfriesgasthuis, Hoorn, The Netherlands

Department of Anesthesiology, VU Medical Center, Amsterdam, The Netherlands

Department of Anesthesiology, Onze Lieve Vrouwen Gasthuis (OLVG), Amsterdam, The Netherlands

Department of Anesthesiology and General Intensive Care, Medical University of Vienna, Austria

Department of Anesthesiology, Hospital Universitari Germans Trias i Pujol, Badalona, Spain

Department of Anesthesiology and Critical Care, Hospital Clinico Universitario de Valencia, Spain

Department of Anesthesiology, Critical Care and Pain Relief, Consorcio Hospital General Universitario de Valencia, Spain

Department of Anesthesiology and Surgical Critical Care, Hospital Universitario La Paz,

Department of Anesthesiology, Hospital Universitari Mútua de Terrassa, Spain

Department of Anesthesiology, Hospital Clinic de Barcelona, Spain

Depts, of Anesthesiology, ${ }^{1}$ King Abdullah Medical City, Makkah, Saudi Arabia \& ${ }^{2}$ Assiut University- EGYPT \& ${ }^{3}$ Mansoura University- EGYPT.

Department of Anesthesiology, King Abdulaziz National Guard Medical City, Riyadh, Saudi Arabia

Department of Anaesthesiology, Istanbul Medica Faculty, Istanbul University, Istanbul, Turkey

Department of Anesthesiology and Reanimation, Marmara University School of Medicine, Istanbul, Turkey

Department of Anesthesiology and Reanimation, Akdeniz University Hospital, Antalya, Turkey

Department of Anesthesiology and Reanimation, Dokuz Eylül University of Medicine, Izmir, Turkey Madrid, Spain
Kacha, Aalok

akacha@dacc.uchicago.edu

Pedemonte, Juan C.

Altermatt, Fernando

Corvetto, Marcia A.

Paredes, Sebastian

Carmona, Javiera

Rolle, Augusto

Bos, Elke

Beurskens, Charlotte

Veering, B

Zonneveldt, Harry

Boer, Christa

Godfried, Marc

Thiel, Bram

Kabon, Barbara

Reiterer, Christian

Canet, Jaume

Tolós, Raquel

Sendra, Mar

González, Miriam

Gómez, Noemí

Ferrando, Carlos

Tania Socorro

Ana Izquierdo

Marina Soro

Granell Gil, Manuel

Hernández Cádiz, María José

Biosca Pérez, Elena

Suarez-de-la-Rica, Alejandro Lopez-Martinez, Mercedes

Huercio, Iván

Maseda, Emilio

Yagüe, Julio

Cebrian Moreno, Alba

Rivas, Eva

Lopez-Baamonde, Manue

1,2 Elgendy, Hamed

${ }^{1,3}$ Sayedalahl,Mohamed

Sibai, Abdul Razak

Yavru, Aysen

Sivrikoz, Nukhet

Karadeniz, Meltem

Corman Dincer, Pelin

Ayanoglu, Hilmi Omer

Tore Altun, Gulbin

Kavas, Ayse Duygu

Dinc, Bora

Kuvaki, Bahar

Ozbilgin, Sule

ayanoglu@mamara.edu.tr jcpedemo@gmail.com

falterma@med.puc.cl

marciacorvetto@gmail.com

sparedese@gmail.com

javiera.carmona.b@gmail.com

arollep@gmail.com

e.m.bos@amc.uva.nl

c.j.beurskens@amc.uva.nl

b.t.h.veering@lumc.nl

h.zonneveldt@westfriesgasthuis.nl

m.w.hollmann@amc.uva.nl

m.b.godfried@olvg.n

b.thiel@olvg.nl

barbara.kabon@meduniwien.ac.at

christian.reiterer@meduniwien.ac.at

jcanet.germanstrias@gencat.cat

rakeltp@yahoo.es

marsendra@gmail.com

miriamgn@hotmail.com

noe6gl@hotmail.com

cafeoranestesia@gmail.com

austania@gmail.com

anaizpa@gmail.com

soromarina@gmail.com

mgranellg@hotmail.com

mj.herca@hotmail.com

ebipe@hotmail.com

alejandro.suarez.delarica@gmail.com mercelopezmartinez@yahoo.es

ivanhuercio@gmail.com

emilio.maseda@gmail.com

juyaru@gmail.com

a.cebrian.moreno@gmail.com

erivas@clinic.ub.es

lopez10@clinic.cat

helgendy70@gmail.com

al-ahl.m@kamc.med.sa

sibaiab@ngha.med.sa

aysenyg@gmail.com

ntsz06@gmail.com

mskaradeniz@gmail.com

pelincorman@yahoo.com

dr_gulbin@yahoo.com

adkavas@hotmail.com

drboradinc@gmail.com

bkuvaki@deu.edu.tr

ozbilginsule@gmail.com 
Table 4 PROBESE investigators (Continued)

Department of Anesthesiology and Reanimation, Fatih Sultan Mehmet Educational and Research Hospital, Istanbul, Turkey

Department of Anaesthesiological, Surgical and Emergency Sciences, Second University of Naples, Italy

Department of Morphology, Surgery and Experimental Medicine, Ospedale Sant' Anna, Ferrara, Italy

Department of Environment, Health and Safety, University of Insubria, Varese, Italy

Dept. of Surgical Sciences and Integrated Diagnostics, IRCCS AOU San Martino, IST, University of Genoa, Italy

Department of Anesthesiology and Reanimation, Ospedale U. Parini, AUSL della Valle d' Aosta, Italy

Department of Anesthesiology, Pharmacology \& Intensive Care, University Hospital Geneva, Switzerland

Institute for Anesthesia and Intensive Care Medicine, Kantonsspital Frauenfeld, Switzerland

Department of Anesthesia, Surgical Intensive Care, Prehospital Emergency Medicine and Pain Therapy, University Hospital Basel, Switzerland

University Department of Anesthesiology, Resuscitation and Intensive Care, University Hospital Sveti Duh, Zagreb, Croatia

Department of Anesthesiology, Resuscitatio and Intensive Care, Clinical Hospital Dubrava, Zagreb, Croatia

Department of Anesthesiology, Ghent University

Department of Anesthesiology, UH Antwerpen, Belgium

Department of Anesthesiology, UZ Leuven, Belgium

Department of Anaesthesiology, Intensive care and Emergency, AZ Sint Jan Brugge, Bruges, Belgium

Department of Anesthesiology, Cliniques Universitaires St Luc, Belgium

Department of Anesthesiology, Ponderas Hospital, Bucharest, Romania

Department of Intensive Care, St James's University Hospital, Dublin, Ireland

\begin{tabular}{|c|c|}
\hline $\begin{array}{l}\text { Erdogan, Dilek } \\
\text { Koksal, Ceren } \\
\text { Abitagaglu, Suheyla }\end{array}$ & $\begin{array}{l}\text { dilekerdoganari@gmail.com } \\
\text { ceren_hazer@yahoo.com } \\
\text { suheylaatay81@gmail.com }\end{array}$ \\
\hline $\begin{array}{l}\text { Aurilio, Caterina } \\
\text { Sansone, Pasquale } \\
\text { Pace, Caterina Maria } \\
\text { Donatiello, Valerio } \\
\text { Mattera, Silvana } \\
\text { Palange, Nazareno } \\
\text { Di Colandrea, Salvatore }\end{array}$ & $\begin{array}{l}\text { caterina.aurilio@unina2.it } \\
\text { pasquale.sansone@unina2.it } \\
\text { caterina.pace@libero.it } \\
\text { valerio.donatiello@gmail.com } \\
\text { silvanamattera@gmail.com } \\
\text { nazareno.palange@gmail.com } \\
\text { di.colandrea@libero.it }\end{array}$ \\
\hline $\begin{array}{l}\text { Spadaro, Savino } \\
\text { Volta, Carlo Alberto } \\
\text { Ragazzi, Riccardo } \\
\text { Ciardo, Stefano } \\
\text { Gobbi, Luca }\end{array}$ & $\begin{array}{l}\text { savinospadaro@gmail.com } \\
\text { vlc@unife.it } \\
\text { rgc@unife.it } \\
\text { stefano.ciardo@student.unife.it } \\
\text { lucagobbi1988@gmail.com }\end{array}$ \\
\hline $\begin{array}{l}\text { Severgnini, Paolo } \\
\text { Bacuzzi, Alessandro } \\
\text { Brugnoni, Elisa }\end{array}$ & $\begin{array}{l}\text { paolo.severgnini@uninsubria.it } \\
\text { alessandro.bacuzzi@gmail.com } \\
\text { elisa.brugnoni@gmail.com }\end{array}$ \\
\hline $\begin{array}{l}\text { Gratarola, Angelo } \\
\text { Micalizzi, Camilla } \\
\text { Simonassi, Francesca } \\
\text { Malerbi, Patrizia }\end{array}$ & $\begin{array}{l}\text { a.gratarola@gmail.com } \\
\text { camilla.micalizzi@gmail.com } \\
\text { fra.simonassi@libero.it } \\
\text { patrizia.malerbi@hsanmartino.it }\end{array}$ \\
\hline Carboni, Adrea & acarboni@ausl.vda.it \\
\hline Licker, Marc-Joseph & marc-joseph.licker@hcuge.ch \\
\hline Dullenkopf, Alexander & alexander.dullenkopf@stgag.ch \\
\hline Goettel, Nicolai & nicolai.goettel@usb.ch \\
\hline $\begin{array}{l}\text { Nesek Adam, Visnja } \\
\text { Karaman Ilić, Maja }\end{array}$ & $\begin{array}{l}\text { visnja.nesek@hotmail.com } \\
\text { majakilic@gmail.com }\end{array}$ \\
\hline $\begin{array}{l}\text { Klaric, Vlasta } \\
\text { Vitkovic, Bibiana } \\
\text { Milic, Morena } \\
\text { Miro, Zupcic }\end{array}$ & $\begin{array}{l}\text { vllastica@gmail.com } \\
\text { bibianavit@hotmail.com } \\
\text { morena.milic@gmail.com } \\
\text { miro_zupcic@yahoo.com }\end{array}$ \\
\hline $\begin{array}{l}\text { De Baerdemaeker, Luc } \\
\text { De Hert, Stefan } \\
\text { Heyse, Bjorn } \\
\text { Van Limmen, Jurgen } \\
\text { Van Nieuwenhove, Yves }\end{array}$ & $\begin{array}{l}\text { luc.debaerdemaeker@ugent.be } \\
\text { stefan.dehert@ugent.be } \\
\text { bjorn.heyse@ugent.be } \\
\text { jurgen.vanlimmen@ugent.be } \\
\text { yves.vannieuwenhove@ugent.be }\end{array}$ \\
\hline Mertens, Els & els.mertens@uza.be \\
\hline Neyrinck, Arne & arne.neyrinck@uzleuven.be \\
\hline Mulier, Jan & jan.mulier@azsintjan.be \\
\hline Kahn, David & david.kahn@uclouvain.be \\
\hline Godoroja, Daniela & danielagodoroja@yahoo.com \\
\hline Martin-Loeches, Martin & drmartinloeches@gmail.com \\
\hline
\end{tabular}
Hospital, Belgium

Erdogan, Dilek

Aurilio, Caterina

Sansone, Pasquale

Donatiello, Valerio

Mattera, Silvana

Spadaro, Savino

Ciardo, Stefano

Cobbi, Luca

Bacuzzi, Alessandro

Brugnoni, Elisa

Malerbi, Patrizia

Carboni, Adrea 
Table 4 PROBESE investigators (Continued)

$151 \quad$ Department of Anaesthesiology and Intensive Care, Zaporozhye State Medical University,

Zaporozhye, Ukraine

152 Department of Anaesthesiology and Intensive Care, Lutsk Clinical Hospital, Lutsk, Ukraine

161 Division of Anesthesiology, Critical Care and Pain Medicine, Tel Aviv Medical Center, Sackler School of Medicine, Tel Aviv, Israel

171 Department of Anaesthesiology and Intensive Therapy, Barlicki University Hospital, Medical University of Lodz, Poland

Department of Anesthesiology and Critical Care, Saint Michael's Hospital, University of Toronto, Canada

Operating Services, Critical Care and Anaesthesia (OSCCA), Sheffield Teaching Hospitals, United Kingdom

Department of Anaesthesia and Critical Care Medicine, University Hospital of North Midlands, Stoke-on-Trent, United Kingdom

Research Divisional Lead - Surgery and Oncology, Research and Development Department, Ashford and St Peter Hospitals NHS Trust, Chertsey, United Kingdom

Department of Anaesthesia, Royal Cornwall Hospital, Truro, United Kingdom

Department of Anaesthesia, Hull and East Yorkshire NHS Trust, Hull, United Kingdom

Department of Critical Care Medicine, Imperial College Healthcare NHS Trust, London, United Kingdom

Department of Anaesthesia, Western Sussex Hospitals NHS Foundation Trust, Chichester, United Kingdom

Department of Anaesthesia, York Teaching Hospitals, York, United Kingdom

Department of Anaesthesia, Homerton University Hospitals NHS Foundation Trust, Homerton, United Kingdom

Department of Anesthesia, Southmead Hospital, Bristol, United Kingdom

Department of Anaesthesia and Critical Care Medicine, University Clinic of Surgery St. Naum Ohridski, Skopje, Macedonia

Department of Anaesthesia, Polyclinique Montier La Celle, St. Andre les Vergers, France

Department of Anaesthesia, Alexandra General Hospital, Athens, Greece

Department of Anaesthesiology and Intensive Medicine, University Hospital of Ostrava Ostrava-Poruba, Czech Republic

Vorotyntsev, Sergiy

Fronchko, Valentyna

Matot, Idit

Goren, Or

Zac, Lilach

Gaszynski, Thomasz

Laffey, Jon

Mills, Gary

Nalwaya, Pramod

Mac Gregor, Mark

Paddle, Jonathan

Balaji, Packianathaswamy

Rubulotta, Francesca

Adebesin, Afeez

Margarson, Mike

Davies, Simon

Rangarajan, Desikan

Newell, Christopher

Shosholcheva, Mirjana

Papaspyros, Fotios

Skandalou, Vasiliki

Dzurňáková, Paula vorotyntsev_s@ukr.net

fron@ua.fm

iditm@tlvmc.gov.il goren.orr@gmail.com isanaesfile@gmail.com

tomasz.gaszynski@umed.lodz.pl

laffeyj@smh.ca

g.h.mills@sheffield.ac.uk

pramod.nalwaya@uhns.nhs.uk

mark.macgregor@asph.nhs.uk

jonathan.paddle@nhs.net

indbalaji@gmail.com

frubulotta@hotmail.com afeez.adebesin@imperial.nhs.uk

michael.margarson@wsht.nhs.uk

drsimondavies@googlemail.com

desikan.rangarajan@homerton.nhs.uk

christopher.newell@doctors.org.uk

sosolceva@hotmail.com

papaspyrosf@outlook.com

vps_71@hotmail.com

paula.dzurnakova@fno.cz 


\section{Appendix 2}

Table 5 Ethics committees that approved the study

\begin{tabular}{|c|c|c|c|}
\hline 001 & Dresden & $\begin{array}{l}\text { Department of Anesthesiology and Intensive } \\
\text { Care Medicine, Pulmonary Engineering Group, } \\
\text { University Hospital Dresden, Germany }\end{array}$ & $\begin{array}{l}\text { Ethics Committee of the Medical Faculty of the Technical } \\
\text { University Dresden } \\
\text { ID: EK } 430112013\end{array}$ \\
\hline 002 & Aachen & $\begin{array}{l}\text { Department of Anesthesiology, University of } \\
\text { Aachen, Germany }\end{array}$ & $\begin{array}{l}\text { Ethics Committee of the Medical Faculty of RWTH Aachen } \\
\text { ID: EK 181/14 }\end{array}$ \\
\hline 003 & Düsseldorf & $\begin{array}{l}\text { Department of Anesthesiology CLIPS Clinical } \\
\text { Trials - Patient-centered Studies, University } \\
\text { Hospital Düsseldorf, Germany }\end{array}$ & $\begin{array}{l}\text { Ethics Committee of the Medical Faculty of HHU Düsseldorf } \\
\text { ID: } 2014072709\end{array}$ \\
\hline 004 & Mainz & $\begin{array}{l}\text { Department of Anaesthesiology, University } \\
\text { Medical Center Mainz, Germany }\end{array}$ & $\begin{array}{l}\text { Ethics Committee of the Medical Faculty of UMC Mainz } \\
\text { ID: } 837.307 .14 \text { (9546) }\end{array}$ \\
\hline 005 & Bochum & $\begin{array}{l}\text { Clinic of Anesthesiology, Intensive Care and } \\
\text { Pain Medicine, University Clinic } \\
\text { Knappschaftskrankenhaus Bochum, Germany }\end{array}$ & $\begin{array}{l}\text { Ethics Committee of the Medical Faculty, Ruhr University } \\
\text { Bochum } \\
\text { ID: } 5110-14\end{array}$ \\
\hline 006 & Heidelberg & $\begin{array}{l}\text { Department of Anesthesiology, University } \\
\text { Hospital Heidelberg, Germany }\end{array}$ & $\begin{array}{l}\text { Ethics Committee of the Medical Faculty, University of } \\
\text { Heidelberg } \\
\text { ID: S- } 442 / 2014\end{array}$ \\
\hline 007 & Wesel & $\begin{array}{l}\text { Department of Anesthesiology, Marienhospital } \\
\text { Wesel, Germany }\end{array}$ & $\begin{array}{l}\text { Ethics Committee of the Medical Council Nordrhein, } \\
\text { Düsseldorf } \\
\text { ID: } 2014497\end{array}$ \\
\hline 008 & Friesoythe & $\begin{array}{l}\text { Department of Anesthesiology and Intensive } \\
\text { Care Medicine, Marienstift Friesoythe, Germany }\end{array}$ & $\begin{array}{l}\text { Ethics Committee of the Medical Council Niedersachsen, } \\
\text { Hannover } \\
\text { ID: Grae/045/2015 }\end{array}$ \\
\hline 009 & Bonn & $\begin{array}{l}\text { Department of Anesthesiology and Intensive } \\
\text { Care Medicine, University Hospital Bonn, Germany }\end{array}$ & $\begin{array}{l}\text { Ethics Committee of the Medical Faculty of the University } \\
\text { of Bonn } \\
\text { ID: } 288 / 15\end{array}$ \\
\hline 011 & Porto & $\begin{array}{l}\text { Serviço de Anestesiologia, Centro Hospitalar } \\
\text { do Porto, Portugal }\end{array}$ & $\begin{array}{l}\text { Ethics and Health Committee of Centro Hospitalar do Porto } \\
\text { ID: } 2014.144 \text { (100-DEFI/130-CES) }\end{array}$ \\
\hline 012 & Santa Maria da Feira & $\begin{array}{l}\text { Serviço de Anestesiologia, Centro Hospitalar } \\
\text { Entre o Douro e Vouga, Santa Maria da Feira, } \\
\text { Portugal }\end{array}$ & $\begin{array}{l}\text { Ethics and Health Committee of Centro Hospitalar Entre o } \\
\text { Douro e Vouga, Santa Maria da Feira } \\
\text { ID: 07/ANES/2014 }\end{array}$ \\
\hline 013 & Porto & $\begin{array}{l}\text { Serviço de Anestesiologia, Centro Hospitalar } \\
\text { São João, Porto, Portugal }\end{array}$ & $\begin{array}{l}\text { Ethics and Health Committee of Centro Hospitalar São João, Porto } \\
\text { ID: CES 167-14 }\end{array}$ \\
\hline 014 & Matosinhos & $\begin{array}{l}\text { Serviço de Anestesiologia, Hospital Pedro } \\
\text { Hispano, Matosinhos, Portugal }\end{array}$ & $\begin{array}{l}\text { Ethics and Health Committee of Hospital Pedro Hispano, } \\
\text { Matosinhos } \\
\text { ID: 076/CE/JAS }\end{array}$ \\
\hline 021 & New York & $\begin{array}{l}\text { Department of Anesthesiology, Montefiore } \\
\text { Medical Center Bronx, New York, NY, USA }\end{array}$ & $\begin{array}{l}\text { Institutional Review Board at Montefiore Medical Center } \\
\text { Bronx, New York } \\
\text { ID: 2014-3761 }\end{array}$ \\
\hline 022 & Rochester, Minnesota & $\begin{array}{l}\text { Department of Anesthesiology, Mayo Clinic, } \\
\text { Rochester, MN, USA }\end{array}$ & $\begin{array}{l}\text { Institutional Review Board Mayo Clinic } \\
\text { ID: } 14-005465\end{array}$ \\
\hline 023 & Jacksonville, Florida & $\begin{array}{l}\text { Department of Anesthesiology, Mayo Clinic, } \\
\text { Jacksonville, FL, USA }\end{array}$ & $\begin{array}{l}\text { Institutional Review Board Mayo Clinic } \\
\text { ID: } 14-005465\end{array}$ \\
\hline 024 & Phoenix, Arizona & $\begin{array}{l}\text { Department of Anesthesiology, Mayo Clinic, } \\
\text { Phoenix, AZ, USA }\end{array}$ & $\begin{array}{l}\text { Institutional Review Board Mayo Clinic } \\
\text { ID: } 14-005465\end{array}$ \\
\hline 025 & Aurora, Colorado & $\begin{array}{l}\text { Department of Anesthesiology, University of } \\
\text { Colorado SOM, Aurora, CO, USA }\end{array}$ & $\begin{array}{l}\text { EColorado Multiple Institutional Review Board (COMIRB) } \\
\text { ID: 14-1495 }\end{array}$ \\
\hline 026 & Boston & $\begin{array}{l}\text { Department of Anesthesiology, Tufts Medical } \\
\text { Center, Boston, MA, USA }\end{array}$ & $\begin{array}{l}\text { Institutional Review Board at Tufts Medical Center, Boston } \\
\text { ID: } 11808\end{array}$ \\
\hline 027 & Jackson & $\begin{array}{l}\text { Department of Anesthesiology, University of } \\
\text { Mississippi, Jackson, MS, USA }\end{array}$ & $\begin{array}{l}\text { Institutional Review Board at University of Mississippi, Jackson } \\
\text { ID: } 2015-0080\end{array}$ \\
\hline 028 & Chicago & $\begin{array}{l}\text { Department of Anesthesiology, University of } \\
\text { Chicago, Chicago, IL, USA }\end{array}$ & $\begin{array}{l}\text { Institutional Review Board at University of Chicago, Chicago } \\
\text { ID: } 14-1044\end{array}$ \\
\hline 031 & Santiago de Chile & $\begin{array}{l}\text { Department of Anesthesiology, Pontificia } \\
\text { Universidad Católica de Chile, Santiago } \\
\text { de Chile, Chile }\end{array}$ & $\begin{array}{l}\text { Comite de Etica en Investigacion Escuela de Medicina Pontificia } \\
\text { Universidad Catolica de Chile } \\
\text { ID: } 14-462\end{array}$ \\
\hline
\end{tabular}


Table 5 Ethics committees that approved the study (Continued)

\begin{tabular}{|c|c|c|c|}
\hline 041 & Amsterdam & $\begin{array}{l}\text { Department of Intensive Care, Academic } \\
\text { Medical Center, University of Amsterdam, } \\
\text { The Netherlands }\end{array}$ & $\begin{array}{l}\text { Medisch Ethische Toetsingscommissie (METC) of the Academic } \\
\text { Medical Center (AMC), Amsterdam } \\
\text { ID: 2014_261 }\end{array}$ \\
\hline 042 & Leiden & $\begin{array}{l}\text { Department of Anesthesiology, Leiden University } \\
\text { Medical Center, Leiden, The Netherlands }\end{array}$ & $\begin{array}{l}\text { Ethics Committee of the Leiden University Medical Center } \\
\text { (LUMC), Leiden } \\
\text { ID: P15.038 }\end{array}$ \\
\hline 043 & Hoorn & $\begin{array}{l}\text { Department of Anesthesiology, Westfriesgasthuis, } \\
\text { Hoorn, The Netherlands }\end{array}$ & $\begin{array}{l}\text { Ethics Committee of Westfriesgasthuis, Hoorn } \\
\text { ID: WB } 486\end{array}$ \\
\hline 044 & Amsterdam & $\begin{array}{l}\text { Department of Anesthesiology, VU Medical } \\
\text { Center, Amsterdam, The Netherlands }\end{array}$ & $\begin{array}{l}\text { Ethics Committee of VU Medical Center (VUMC), Amsterdam } \\
\text { ID: } 2014.561\end{array}$ \\
\hline 045 & Amsterdam & $\begin{array}{l}\text { Department of Anesthesiology, Onze Lieve } \\
\text { Vrouwen Gasthuis (OLVG), Amsterdam, } \\
\text { The Netherlands }\end{array}$ & $\begin{array}{l}\text { Ethics Committee of the Onze Lieve Vrouwen Gasthuis (OLVG), } \\
\text { Amsterdam } \\
\text { ID: WO } 14.133\end{array}$ \\
\hline 051 & Vienna & $\begin{array}{l}\text { Department of Anesthesiology and General } \\
\text { Intensive Care, Medical University of Vienna, } \\
\text { Austria }\end{array}$ & $\begin{array}{l}\text { Ethics committee of the Medical University of Vienna } \\
\text { ID: } 1702 / 2014\end{array}$ \\
\hline 061 & Badalona & $\begin{array}{l}\text { Department of Anesthesiology, Hospital } \\
\text { Universitari Germans Trias i Pujol, Badalona, } \\
\text { Spain }\end{array}$ & $\begin{array}{l}\text { Comité d'Ėtica de la Investigació. Hospital Universitari Germans } \\
\text { Trias i Pujol, Badalona } \\
\text { ID: AC-14-095 }\end{array}$ \\
\hline 062 & Valencia & $\begin{array}{l}\text { Department of Anesthesiology and Critical } \\
\text { Care, Hospital Clinico Universitario de } \\
\text { Valencia, Spain }\end{array}$ & $\begin{array}{l}\text { Ethics Committee of the Hospital Clinico Universitario de Valencia } \\
\text { ID: F-CE-GEva-15, approved 27/11/2014 }\end{array}$ \\
\hline 063 & Valencia & $\begin{array}{l}\text { Department of Anesthesiology, Critical Care and } \\
\text { Pain Relief, Consorcio Hospital General } \\
\text { Universitario de Valencia, Spain }\end{array}$ & $\begin{array}{l}\text { Ethics Committee of the Consorcio Hospital General Universitario } \\
\text { of Valencia } \\
\text { ID: } 223 / 2004\end{array}$ \\
\hline 064 & Madrid & $\begin{array}{l}\text { Department of Anesthesiology and Surgical } \\
\text { Critical Care, Hospital Universitario La Paz, } \\
\text { Madrid, Spain }\end{array}$ & $\begin{array}{l}\text { Ethics Committee of the Hospital Universitario La Paz, Madrid } \\
\text { ID: } 4465 \text { 12/2015 }\end{array}$ \\
\hline 065 & Terrassa & $\begin{array}{l}\text { Department of Anesthesiology, Hospital } \\
\text { Universitari Mútua de Terrassa, Spain }\end{array}$ & $\begin{array}{l}\text { Ethics Committee of the Hospital Universitari Mútua de Terrassa, } \\
\text { Terassa } \\
\text { ID: 04/15, approved 29/04/2015 }\end{array}$ \\
\hline 066 & Barcelona & $\begin{array}{l}\text { Department of Anesthesiology, Hospital } \\
\text { Clinic de Barcelona, Spain }\end{array}$ & $\begin{array}{l}\text { Research Ethics Committee of the Hospital Clínic of Barcelona } \\
\text { ID: HCB/2015/0963 }\end{array}$ \\
\hline 071 & Makkah & $\begin{array}{l}\text { Department of Anesthesiology, King Abdullah } \\
\text { Medical City, Makkah, Saudi Arabia }\end{array}$ & $\begin{array}{l}\text { King Abdullah Medical City (KAMC) Local IRB registered at } \\
\text { the National BioMedical Ethics Committee, King Abdulaziz } \\
\text { City for Science and Technology } \\
\text { ID: } 14-144\end{array}$ \\
\hline 072 & Riyadh & $\begin{array}{l}\text { Department of Anesthesiology, King Abdulaziz } \\
\text { National Guard Medical City, Riyadh, Saudi Arabia }\end{array}$ & $\begin{array}{l}\text { Ethics Committee of the King Abdulaziz National Guard Medical } \\
\text { City, Riyadh } \\
\text { ID: IRBC/215/16 }\end{array}$ \\
\hline 081 & Istanbul & $\begin{array}{l}\text { Department of Anaesthesiology, Istanbul Medical } \\
\text { Faculty, Istanbul University, Istanbul, Turkey }\end{array}$ & $\begin{array}{l}\text { Clinical Research Ethics Committee of the Istanbul Faculty } \\
\text { of Medicine, Istanbul University, Istanbul } \\
\text { IB: 1417, approved 18/9/2014 }\end{array}$ \\
\hline 082 & Istanbul & $\begin{array}{l}\text { Department of Anesthesiology and Reanimation, } \\
\text { Marmara University School of Medicine, } \\
\text { Istanbul, Turkey }\end{array}$ & $\begin{array}{l}\text { Clinical Research Ethics Committee of the Istanbul Faculty } \\
\text { of Medicine, Istanbul } \\
\text { ID: } 09.2015075\end{array}$ \\
\hline 083 & Antalya & $\begin{array}{l}\text { Department of Anesthesiology and Reanimation, } \\
\text { Akdeniz University Hospital, Antalya, Turkey }\end{array}$ & $\begin{array}{l}\text { Ethics Committee of Akdeniz University Hospital, Antalya } \\
\text { ID: } 170 \text {, approved 17/04/2015 }\end{array}$ \\
\hline 084 & Izmir & $\begin{array}{l}\text { Department of Anesthesiology and Reanimation, } \\
\text { Dokuz Eylül University of Medicine, Izmir, Turkey }\end{array}$ & $\begin{array}{l}\text { Ethics Committee of Dokuz Eylul University Medical Faculty } \\
\text { ID: 66, approved 23/01/2015 }\end{array}$ \\
\hline 085 & Istanbul & $\begin{array}{l}\text { Department of Anesthesiology and Reanimation, } \\
\text { Fatih Sultan Mehmet Educational and Research } \\
\text { Hospital, Istanbul, Turkey }\end{array}$ & $\begin{array}{l}\text { Ethics committee of Fatih Sultan Mehmet Educational and } \\
\text { Research Hospital, Istanbul } \\
\text { ID: } 17073117-050-99\end{array}$ \\
\hline 091 & Napoli & $\begin{array}{l}\text { Department of Anaesthesiological, Surgical and } \\
\text { Emergency Sciences, Second University of }\end{array}$ & $\begin{array}{l}\text { Ethics committee of Second University of Naples } \\
\text { ID: } 29 . G E N .2015 / 128\end{array}$ \\
\hline
\end{tabular}


Table 5 Ethics committees that approved the study (Continued)

\begin{tabular}{|c|c|c|c|}
\hline 092 & Ferrara & $\begin{array}{l}\text { Department of Morphology, Surgery and } \\
\text { Experimental Medicine, Ospedale Sant' Anna, } \\
\text { Ferrara, Italy }\end{array}$ & $\begin{array}{l}\text { Ethics Committee of Ferrara } \\
\text { ID: } 15097 \text {, approved 26/03/2015 }\end{array}$ \\
\hline 093 & Varese & $\begin{array}{l}\text { Department of Environment, Health and Safety, } \\
\text { University of Insubria, Varese, Italy }\end{array}$ & $\begin{array}{l}\text { Ethics Committee - ASST Sette Laghi Ospedale di Circolo } \\
\text { e Fondazione Macchi, Varese, Italy } \\
\text { ID: } 0034259\end{array}$ \\
\hline 094 & Genoa & $\begin{array}{l}\text { Dept. of Surgical Sciences and Integrated } \\
\text { Diagnostics, IRCCS AOU San Martino, IST, } \\
\text { University of Genoa, Italy }\end{array}$ & $\begin{array}{l}\text { Regional Ethics Committee Liguria, Italy } \\
\text { ID: } 121 \text {.REG.2015 }\end{array}$ \\
\hline 095 & Aosta & $\begin{array}{l}\text { Department of Anesthesiology and Reanimation, } \\
\text { Ospedale U. Parini, AUSL della Valle d'Aosta, Italy }\end{array}$ & $\begin{array}{l}\text { Ethics Committee of AUSL della Valle d' Aosta, Aosta } \\
\text { ID: 737, approved 19/06/2015 }\end{array}$ \\
\hline 101 & Geneva & $\begin{array}{l}\text { Department of Anesthesiology, Pharmacology } \\
\text { \& Intensive Care, University Hospital Geneva, } \\
\text { Switzerland }\end{array}$ & $\begin{array}{l}\text { Ethics Committee of University Hospital Geneva } \\
\text { ID: } 14-238\end{array}$ \\
\hline 102 & Frauenfeld & $\begin{array}{l}\text { Department of Anesthesiology and Intensive } \\
\text { Care, Kantonsspital Frauenfeld, Switzerland }\end{array}$ & $\begin{array}{l}\text { Ethics Committee of the Kanton Thurgau, Münsterlingen } \\
\text { ID: A2015/33 }\end{array}$ \\
\hline 103 & Basel & $\begin{array}{l}\text { Department of Anesthesia, Surgical Intensive } \\
\text { Care, Prehospital Emergency Medicine and } \\
\text { Pain Therapy, University Hospital Basel, } \\
\text { Switzerland }\end{array}$ & $\begin{array}{l}\text { Ethikkommission Nordwest- und Zentralschweiz } \\
\text { ID: PB_2016-00313 }\end{array}$ \\
\hline 111 & Zagreb & $\begin{array}{l}\text { University Department of Anesthesiology, } \\
\text { Resuscitation and Intensive Care, University } \\
\text { Hospital Sveti Duh, Zagreb, Croatia }\end{array}$ & $\begin{array}{l}\text { Ethics Committee of the Clinical Hospital Sveti Duh } \\
\text { ID: } 01-12 / 4\end{array}$ \\
\hline 112 & Zagreb & $\begin{array}{l}\text { Department of Anesthesiology, Resuscitation } \\
\text { and Intensive Care, Clinical Hospital Dubrava, } \\
\text { Zagreb, Croatia }\end{array}$ & $\begin{array}{l}\text { Ethics Committee of the University Zagreb School of Medicine } \\
\text { and Ethics Committee of Clinical Hospital Dubrava Zagreb } \\
\text { ID: none provided, approved 23/06/2015 }\end{array}$ \\
\hline 121 & Ghent & $\begin{array}{l}\text { Department of Anesthesiology, Ghent University } \\
\text { Hospital, Belgium }\end{array}$ & $\begin{array}{l}\text { Ethics Committee of Ghent University Hospital } \\
\text { ID: B670201523757 }\end{array}$ \\
\hline 123 & Antwerpen & $\begin{array}{l}\text { Department of Anesthesiology, UH Antwerpen, } \\
\text { Belgium }\end{array}$ & $\begin{array}{l}\text { Ethics Committee of Ghent University Hospital } \\
\text { ID: B670201523757 }\end{array}$ \\
\hline 124 & Leuven & $\begin{array}{l}\text { Department of Anesthesiology, UZ Leuven, } \\
\text { Belgium }\end{array}$ & $\begin{array}{l}\text { Ethics Committee of Ghent University Hospital } \\
\text { ID: B670201523757 }\end{array}$ \\
\hline 125 & Bruges & $\begin{array}{l}\text { Department of Anaesthesiology, Intensive care } \\
\text { and Emergency, AZ Sint Jan Brugge, Bruges, } \\
\text { Belgium }\end{array}$ & $\begin{array}{l}\text { Ethics Committee of Ghent University Hospital } \\
\text { ID: B670201523757 }\end{array}$ \\
\hline 126 & Brussels & $\begin{array}{l}\text { Department of Anesthesiology, Cliniques } \\
\text { Universitaires St Luc, Belgium }\end{array}$ & $\begin{array}{l}\text { Ethics Committee of Ghent University Hospital } \\
\text { ID: B670201523757 }\end{array}$ \\
\hline 131 & Bucharest & $\begin{array}{l}\text { Department of Anesthesiology, Ponderas } \\
\text { Hospital, Bucharest, Romania }\end{array}$ & $\begin{array}{l}\text { Ethic Council of the Ponderas Hospital, Bucharest } \\
\text { ID: } 73 \text {, approved /23/06/2015 }\end{array}$ \\
\hline 141 & Dublin & $\begin{array}{l}\text { Department of Critical Care and burns unit, SR } \\
\text { James's University Hospital, Dublin, Ireland }\end{array}$ & $\begin{array}{l}\text { Ethics Committee of St. James's University Hospital, Dublin } \\
\text { ID: 2015/05/02 }\end{array}$ \\
\hline 151 & Zaporozhye & $\begin{array}{l}\text { Department of Anaesthesiology and Intensive } \\
\text { Care, Zaporozhye State Medical University, } \\
\text { Zaporozhye, Ukraine }\end{array}$ & $\begin{array}{l}\text { Ethics Committee of the Zaporozhye State Medical University, } \\
\text { Zaporozhye } \\
\text { ID: } 5 / 2015\end{array}$ \\
\hline 152 & Lutsk & $\begin{array}{l}\text { Department of Anaesthesiology and Intensive } \\
\text { Care, Lutsk Clinical Hospital, Lutsk, Ukraine }\end{array}$ & $\begin{array}{l}\text { Ethics Committee of the Lutsk Clinical Hospital, Lutsk } \\
\text { ID: } 354 / 1.3 .7 .15\end{array}$ \\
\hline 161 & Tel Aviv & $\begin{array}{l}\text { Division of Anesthesiology, Critical Care and Pain } \\
\text { Medicine, Tel Aviv Medical Center, Sackler } \\
\text { School of Medicine, Tel Aviv, Israel }\end{array}$ & $\begin{array}{l}\text { Tel Aviv Medical Center Helsinki Committee } \\
\text { ID: 0509-14-TLV }\end{array}$ \\
\hline 171 & Lodz & $\begin{array}{l}\text { Department of Anaesthesiology and Intensive } \\
\text { Therapy, Barlicki University Hospital, Medical } \\
\text { University of Lodz, Poland }\end{array}$ & $\begin{array}{l}\text { Ethics Committee of Medical University of Lodz, Poland } \\
\text { ID: RNN/134/15/KE }\end{array}$ \\
\hline 181 & Toronto & $\begin{array}{l}\text { Department of Anesthesiology and Critical Care, } \\
\text { Saint Michael's Hospital, University of Toronto, } \\
\text { Canada }\end{array}$ & $\begin{array}{l}\text { St Michael's Hospital Research Ethics Board } \\
\text { ID: } 15-134\end{array}$ \\
\hline 191 & Sheffield & $\begin{array}{l}\text { Operating Services, Critical Care and Anaesthesia } \\
\text { (OSCCA), Sheffield Teaching Hospitals, United }\end{array}$ & $\begin{array}{l}\text { NISCHR Research Ethics Service, Wales REC4,Wrexham } \\
\text { ID: 15/WA/0106 }\end{array}$ \\
\hline
\end{tabular}


Table 5 Ethics committees that approved the study (Continued)

\begin{tabular}{|c|c|c|c|}
\hline 192 & Stoke-on-Trent & $\begin{array}{l}\text { Department of Anaesthesia and Critical Care } \\
\text { Medicine, University Hospital of North Midlands, } \\
\text { Stoke-on-Trent, United Kingdom }\end{array}$ & $\begin{array}{l}\text { NISCHR Research Ethics Service, Wales REC4,Wrexham } \\
\text { ID: 15/WA/0106 }\end{array}$ \\
\hline 193 & Chertsey & $\begin{array}{l}\text { Research Divisional Lead - Surgery and Oncology, } \\
\text { Research and Development Department, Ashford } \\
\text { and St Peter Hospitals NHS Trust, Chertsey, } \\
\text { United Kingdom }\end{array}$ & $\begin{array}{l}\text { NISCHR Research Ethics Service, Wales REC4,Wrexham } \\
\text { ID: 15/WA/0106 }\end{array}$ \\
\hline 194 & Truro & $\begin{array}{l}\text { Department of Anaesthesia, Royal Cornwall } \\
\text { Hospital, Truro, United Kingdom }\end{array}$ & $\begin{array}{l}\text { NISCHR Research Ethics Service, Wales REC4,Wrexham } \\
\text { ID: 15/WA/0106 }\end{array}$ \\
\hline 195 & Hull & $\begin{array}{l}\text { Department of Anaesthesia, Hull and East } \\
\text { Yorkshire NHS Trust, Hull, United Kingdom }\end{array}$ & $\begin{array}{l}\text { NISCHR Research Ethics Service, Wales REC4,Wrexham } \\
\text { ID: 15/WA/0106 }\end{array}$ \\
\hline 196 & London & $\begin{array}{l}\text { Department of Critical Care Medicine, Imperial } \\
\text { College Healthcare NHS Trust, London, } \\
\text { United Kingdom }\end{array}$ & $\begin{array}{l}\text { NISCHR Research Ethics Service, Wales REC4,Wrexham } \\
\text { ID: 15/WA/0106 }\end{array}$ \\
\hline 197 & Chichester & $\begin{array}{l}\text { Department of Anaesthesia, Western Sussex } \\
\text { Hospitals NHS Foundation Trust, Chichester, } \\
\text { United Kingdom }\end{array}$ & $\begin{array}{l}\text { NISCHR Research Ethics Service, Wales REC4,Wrexham } \\
\text { ID: 15/WA/0106 }\end{array}$ \\
\hline 198 & York & $\begin{array}{l}\text { Department of Anaesthesia, York Teaching } \\
\text { Hospitals, York, United Kingdom }\end{array}$ & $\begin{array}{l}\text { NISCHR Research Ethics Service, Wales REC4,Wrexham } \\
\text { ID: 15/WA/0106 }\end{array}$ \\
\hline 199 & Homerton & $\begin{array}{l}\text { Department of Anaesthesia, Homerton University } \\
\text { Hospitals NHS Foundation Trust, Homerton, } \\
\text { United Kingdom }\end{array}$ & $\begin{array}{l}\text { NISCHR Research Ethics Service, Wales REC4,Wrexham } \\
\text { ID: 15/WA/0106 }\end{array}$ \\
\hline 190 & Bristol & $\begin{array}{l}\text { Department of Anaesthesia, Southmead Hospital, } \\
\text { Bristol, United Kingdom }\end{array}$ & $\begin{array}{l}\text { NISCHR Research Ethics Service, Wales REC4,Wrexham } \\
\text { ID: 15/WA/0106 }\end{array}$ \\
\hline 201 & Skopje & $\begin{array}{l}\text { Department of Anaesthesia and Critical Care } \\
\text { Medicine, University Clinic of Surgery St. Naum } \\
\text { Ohridski, Skopje, Macedonia }\end{array}$ & $\begin{array}{l}\text { Ethic Committee of the University Hospital Skopje } \\
\text { ID: } 07 / 3183 / 1\end{array}$ \\
\hline 211 & St. Andre les Vergers & $\begin{array}{l}\text { Department of Anaesthesia, Polyclinique Montier } \\
\text { La Celle, St. Andre les Vergers, France }\end{array}$ & $\begin{array}{l}\text { Ethic Committee of the Polyclinique Montier La Celle, St. } \\
\text { Andre les Vergers } \\
\text { ID: non provided; approved 16/03/2016 }\end{array}$ \\
\hline \multirow[t]{2}{*}{221} & Athens & $\begin{array}{l}\text { Department of Anaesthesia, Alexandra General } \\
\text { Hospital, Athens, Greece }\end{array}$ & $\begin{array}{l}\text { Ethic Committee of the Alexandra General Hospital, Athens } \\
\text { ID: } 18-8 / 21-06-2016\end{array}$ \\
\hline & Ostrava-Poruba & $\begin{array}{l}\text { Department of Anaesthesiology and Intensive } \\
\text { Medicine, University Hospital of Ostrava, } \\
\text { Ostrava-Poruba, Czech Republic }\end{array}$ & $\begin{array}{l}\text { Ethic Committee of the University Hospital of Ostrava, } \\
\text { Ostrava-Poruba } \\
\text { ID: } 64 / 2015\end{array}$ \\
\hline
\end{tabular}

\section{Additional files}

Additional file 1: PROBESE Study protocol version 2.5. This PDF file includes the most recent version of the PROBESE Study protocol with changes highlighted. (PDF 870 kb)

Additional file 2: Standard Protocol Items: Recommendations for Interventional Trials (SPIRIT) 2013 checklist: recommended items to address in a clinical trial protocol and related documents. (PDF $122 \mathrm{~kb}$ ).

Additional file 3: PROBESE case report form version 1.2.2. This file corresponds to the paper version of the case report form. (DOC $1610 \mathrm{~kb}$ ).

Additional file 4: Standard operating procedures (SOP) for plasma Sampling. (PDF $115 \mathrm{~kb}$ )

Additional file 5: Standard operating procedures (SOP) for plasma Sampling. (PDF $110 \mathrm{~kb}$ )

\section{Abbreviations}

AE: Adverse event; ARDS: Acute respiratory distress syndrome; ARISCAT: Assess Respiratory Risk in Surgical Patients in Catalonia; BMl: Body mass index; CONSORT: Consolidated Standards of Reporting Trials; COPD: Chronic obstructive pulmonary disease; CRF: Case report form; DIC: Disseminated intravascular coagulation; DSMB: Data and Safety Monitoring Board; $\mathrm{FiO}_{2}$ : Fraction of inspired oxygen; GIF: Gastrointestinal failure; I:E: Inspiratory-to-expiratory ratio; ICU: Intensive care unit; INR: International normalized ratio;
ITT: Intention-to-treat; OSA: Obstructive sleep apnea; $\mathrm{PaO}_{2}$ : Partial pressure of arterial oxygen; PBW: Predicted body weight; PEEP: Positive end-expiratory pressure; PEPC: Postoperative extrapulmonary complication; POD: Postoperative day; PPC: Postoperative pulmonary complication; Ppeak: Peak airway pressure; Pplat: Plateau airway pressure; PROBESE trial: PRotective Ventilation with Higher versus Lower PEEP during General Anesthesia for Surgery in OBESE Patients; REDCap ${ }^{\mathrm{TM}}$ : Research Electronic Data Capture (web-based system used during PROBESE as electronic case report form); RIFLE classification system: Risk, injury, failure, loss, end-stage kidney disease; RM: Recruitment maneuver; RR: Respiratory rate; SPIRIT: Standard Protocol Items: Recommendations for Interventional Trials; $\mathrm{SpO}_{2}$ : Peripheral oxyhemoglobin saturation measured by pulse oximetry; SSL: Secure Sockets Layer; VAS: Visual analogue scale; $V_{\text {T: }}$ Tidal volume; WHO: World Health Organization

\section{Acknowledgements}

We thank Marko Kaeppler for building and maintaining the electronic CRF, as well as the team of the Clinical Trial Network of the European Society of Anaesthesiology (ESA) for organizational support, study promotion, and on-site monitoring: Brigitte Leva, Sandrine Damster, Benoit Plichon, Julia Dowell, and Pierre Harlet. We are also thankful to Edward J. Mascha, PhD, from the Department of Quantitative Health Sciences and the Department of Anesthesia Outcomes Research, Cleveland Clinic, Cleveland, OH, USA, for statistical advice regarding adjustment of sample sizes. We are indebted to all the PROBESE investigators listed in Appendix 1. 


\section{Availability of data and materials}

The datasets analyzed during the present study are available from the corresponding author on reasonable request.

\section{Authors' contributions}

TB conceived and designed the study, coordinates the overall study and drafted the manuscript. RT participated in the design of the study and contributed to the final manuscript. TK participated in the design of the study and contributed to the final manuscript. IB participated in the design of the study and contributed to the final manuscript. JC participated in the design of the study, coordinates the study in Spain and contributed to the final manuscript. GC participated in the design of the study and contributed to the final manuscript. LdB participated in the design of the study, coordinates the study in Belgium and contributed to the final manuscript. CG participated in the design of the study and contributed to the final manuscript. GH participated in the design of the study and contributed to the final manuscript. SNH participated in the design of the study, cocoordinates the study in the Netherlands and contributed to the final manuscript. MH participated in the design of the study and contributed to the final manuscript. MWH participated in the design of the study, coordinates the study in The Netherlands and contributed to the final manuscript. SJ participated in the design of the study and contributed to the final manuscript. JGL participated in the design of the study, coordinates the study in Canada and contributed to the final manuscript. MJL participated in the design of the study, coordinates the study in Switzerland and contributed to the final manuscript. KM participated in the design of the study, coordinates the study in Austria and contributed to the final manuscript. IM participated in the design of the study and contributed to the final manuscript. GM performed the sample size calculation, drafted the statistical analysis plan and contributed to the final manuscript. GHM participated in the design of the study, coordinates the study in the United Kingdom and contributed to the final manuscript. JPM participated in the design of the study and contributed to the final manuscript. CP participated in the design of the study and contributed to the final manuscript. RR participated in the design of the study and contributed to the final manuscript. JSc drafted the statistical analysis plan and contributed to the final manuscript. MS participated in the design of the study, coordinates the study in Turkey and contributed to the final manuscript. ASN participated in the design of the study, monitors and reports adverse events and contributed to the final manuscript. PS participated in the design of the study and contributed to the final manuscript. JSp participated in the design of the study, coordinates the study in the United States and contributed to the final manuscript. MFVM participated in the design of the study and contributed to the final manuscript. HW participated in the design of the study, coordinates the study in Germany and contributed to the final manuscript. MJS conceived and designed the study and drafted the manuscript. PP conceived and designed the study and drafted the manuscript. MGdA conceived and designed the study and drafted the manuscript. All authors read and approved the final manuscript.

\section{Authors' information}

Not applicable.

\section{Competing interests}

The authors declare that they have no competing interests.

\section{Consent for publication}

Not applicable.

\section{Publisher's Note}

Springer Nature remains neutral with regard to jurisdictional claims in published maps and institutional affiliations.

\section{Author details}

'Pulmonary Engineering Group, Department of Anesthesiology and Intensive Care Medicine, University Hospital Carl Gustav Carus, Dresden, Germany. ${ }^{2}$ Aneszteziológiai és Intenzív Terápiás Klinika, Semmelweis Egyetem, Budapest, Hungary. ${ }^{3}$ Department of Anesthesiology, Hospital Universitari Germans Trias i Pujol, Badalona, Spain. ${ }^{4}$ Department of Anesthesiology and Intensive Care Medicine, University of Foggia, Foggia, Italy. ${ }^{5}$ Department of Anesthesiology, Ghent University Hospital, Ghent, Belgium. ${ }^{6}$ Department of Biopathology and Medical Biotechnologies, Policlinico "P. Giaccone", Palermo,
Italy. ${ }^{7}$ Section of Clinical Physiology, Department of Medical Sciences, University Hospital, Uppsala, Sweden. ${ }^{8}$ Department of Anesthesiology, Academic Medical Center, University of Amsterdam, Amsterdam, The Netherlands. 'Laboratory of Experimental Intensive Care and Anesthesiology (L.E.I.C.A), Academic Medical Center, University of Amsterdam, Amsterdam, The Netherlands. ${ }^{10}$ Division of Cardiac Surgery, Medical University of Vienna, Vienna, Austria. " Division of Thoracic Surgery, Medical University of Vienna, Vienna, Austria. ${ }^{12}$ Division of Vascular Surgery, Medical University of Vienna, Vienna, Austria. ${ }^{13}$ Department of Anesthesia, Intensive Care and Pain Medicine, Medical University of Vienna, Vienna, Austria. ${ }^{14}$ Department of Critical Care Medicine and Anesthesiology (SAR B), Saint Eloi University Hospital, Montpellier, France. ${ }^{15}$ Critical Care Medicine Program, Department of Anesthesia, Saint Michael's Hospital, Toronto, ON, Canada. ${ }^{16}$ Department of Anesthesia, University of Toronto, Toronto, ON, Canada. ${ }^{17}$ Department of Physiology, University of Toronto, Toronto, ON, Canada. ${ }^{18}$ Interdepartmental Division of Critical Care Medicine, University of Toronto, Toronto, ON, Canada. ${ }^{19}$ Department of Anesthesiology, Pharmacology and Intensive Care, University Hospital Geneva, Geneva, Switzerland. ${ }^{20}$ Department of Anesthesia, Intensive Care and Pain Medicine, Medical University of Vienna, Vienna, Austria. ${ }^{21}$ Department of Anesthesiology and Critical Care, Tel Aviv Medical Center, Sackler School of Medicine, Tel Aviv University, Tel Aviv, Israel. ${ }^{22}$ Center for Evidence-based Healthcare, University Hospital and Medical Faculty Carl Gustav Carus, Technical University Dresden, Dresden, Germany. ${ }^{23}$ Operating Services, Critical Care and Anaesthesia (OSCCA), Sheffield Teaching Hospitals and University of Sheffield, Sheffield, UK. ${ }^{24}$ Department of Anesthesiology, AZ Sint Jan Brugge-Oostende AV, Brugge, Belgium. ${ }^{25}$ Department of Anesthesiology and Intensive Care Medicine, University of Bonn, Bonn, Germany. ${ }^{26}$ Department of Anesthesiology, University of Aachen, Aachen, Germany. ${ }^{27}$ Department of Anesthesiology and Intensive Care Medicine, Istanbul Medical Faculty, University of Istanbul, Istanbul, Turkey. ${ }^{28}$ Department of Critical Care Medicine, Hospital Israelita Albert Einstein, Faculdade de Medicina do ABC, São Paulo, Brazil. ${ }^{29}$ Program of Post-Graduation, Research and Innovation, Faculdade de Medicina do ABC, São Paulo, Brazil. ${ }^{30}$ Department of Biotechnology and Sciences of Life, University of Insubria, ASST dei Sette Laghi, Ospedale di Cricolo e Fondazione Macchi, Varese, Italy. ${ }^{31}$ Department of Anesthesiology, Mayo Clinic, Rochester, MN, USA. ${ }^{32}$ Department of Anesthesia, Critical Care and Pain Medicine, Massachusetts General Hospital, Harvard Medical School, Boston, MA, USA. ${ }^{33}$ Department of Anesthesiology and Intensive Care Medicine, University of Leipzig, Leipzig, Germany. ${ }^{34}$ Department of Intensive Care, Academic Medical Center, University of Amsterdam, Amsterdam, The Netherlands. ${ }^{35}$ Department of Surgical Sciences and Integrated Diagnostics, IRCCS AOU San Martino - IST, University of Genoa, Genoa, Italy.

Received: 4 October 2016 Accepted: 29 March 2017 Published online: 28 April 2017

\section{References}

1. Mazo V, Sabate S, Canet J, Gallart L, de Abreu MG, Belda J, et al. Prospective external validation of a predictive score for postoperative pulmonary complications. Anesthesiology. 2014;121:219-31.

2. Serpa Neto A, Hemmes SN, Barbas CS, Beiderlinden M, Fernandez-Bustamante $A$, Futier $E$, et al. Incidence of mortality and morbidity related to postoperative lung injury in patients who have undergone abdominal or thoracic surgery: a systematic review and meta-analysis. Lancet Respir Med. 2014;2:1007-15.

3. Canet J, Sabaté S, Mazo V, Gallart L, de Abreu MG, Belda J, et al. Development and validation of a score to predict postoperative respiratory failure in a multicentre European cohort: a prospective, observational study. Eur J Anaesthesiol. 2015;32:458-70.

4. Guldner A, Kiss T, Serpa Neto A, Hemmes SN, Canet J, Spieth PM, et al. Intraoperative protective mechanical ventilation for prevention of postoperative pulmonary complications: a comprehensive review of the role of tidal volume, positive end-expiratory pressure, and lung recruitment maneuvers. Anesthesiology. 2015;123:692-713.

5. Weiser TG, Makary MA, Haynes AB, Dziekan G, Berry WR, Gawande AA. Standardised metrics for global surgical surveillance. Lancet. 2009;374:11 13-7.

6. Serpa Neto A, Hemmes SN, Barbas CS, Beiderlinden M, Biehl M, Binnekade JM, et al. Protective versus conventional ventilation for surgery: a systematic review and individual patient data meta-analysis. Anesthesiology. 2015;123:66-78.

7. PROVE Network Investigators for the Clinical Trial Network of the European Society of Anaesthesiology. High versus low positive end-expiratory pressure 
during general anaesthesia for open abdominal surgery (PROVHILO trial): a multicentre randomised controlled trial. Lancet. 2014;384:495-503.

8. Pelosi P, Croci M, Ravagnan I, Vicardi P, Gattinoni L. Total respiratory system, lung, and chest wall mechanics in sedated-paralyzed postoperative morbidly obese patients. Chest. 1996;109:144-51.

9. Pelosi P, Croci M, Ravagnan I, Tredici S, Pedoto A, Lissoni A, et al. The effects of body mass on lung volumes, respiratory mechanics, and gas exchange during general anesthesia. Anesth Analg. 1998;87:654-60.

10. Pelosi P, Gregoretti C. Perioperative management of obese patients. Best Pract Res Clin Anaesthesiol. 2010;24:211-25.

11. Jaber S, Coisel Y, Chanques G, Futier E, Constantin JM, Michelet P, et al. A multicentre observational study of intra-operative ventilatory management during general anaesthesia: tidal volumes and relation to body weight. Anaesthesia. 2012;67:999-1008.

12. Futier $E$, Marret $E$, Jaber $S$. Perioperative positive pressure ventilation: an integrated approach to improve pulmonary care. Anesthesiology. 2014;121:400-8.

13. Canet J, Gallart L, Gomar C, Paluzie G, Valles J, Castillo J, et al. Prediction of postoperative pulmonary complications in a population-based surgical cohort. Anesthesiology. 2010;113:1338-50.

14. Crapo RO, Morris AH, Gardner RM. Reference spirometric values using techniques and equipment that meet ATS recommendations. Am Rev Respir Dis. 1981;123: 659-64.

15. Crapo RO, Morris AH, Clayton PD, Nixon CR. Lung volumes in healthy nonsmoking adults. Bull Eur Physiopathol Respir. 1982;18:419-25.

16. Morrison LJ, Deakin CD, Morley PT, Callaway CW, Kerber RE, Kronick SL, et al. Part 8: Advanced life support: 2010 International Consensus on Cardiopulmonary Resuscitation and Emergency Cardiovascular Care Science with Treatment Recommendations. Circulation. 2010;122(16 Suppl 2):S345-421.

17. Definition Task Force ARDS. Acute respiratory distress syndrome: the Berlin Definition. JAMA. 2012;307:2526-33.

18. Levy MM, Fink MP, Marshall JC, Abraham E, Angus D, Cook D, et al. 2001 SCCM/ESICM/ACCP/ATS/SIS International Sepsis Definitions Conference. Crit Care Med. 2003;31:1250-6.

19. Thygesen K, Alpert JS, White HD. Joint ESC/ACCF/AHA/WHF Task Force for the Redefinition of Myocardial Infarction. Universal definition of myocardial infarction. Circulation. 2007;1 16:2634-53.

20. Bellomo R, Ronco C, Kellum JA, Mehta RL, Palevsky P, Acute Dialysis Quality Initiative workgroup. Acute Dialysis Quality Initiative w: Acute renal failure definition, outcome measures, animal models, fluid therapy and information technology needs: the Second International Consensus Conference of the Acute Dialysis Quality Initiative (ADQI) Group. Crit Care. 2004;8:R204-12.

21. Levi M, Toh CH, Thachil J, Watson HG. Guidelines for the diagnosis and management of disseminated intravascular coagulation. Br J Haematol. 2009:145:24-33.

22. Reintam A, Parm P, Kitus R, Starkopf J, Kern H. Gastrointestinal failure score in critically ill patients: a prospective observational study. Crit Care. 2008;12:R90.

23. Du ZG, Wei YG, Chen KF, Li B. An accurate predictor of liver failure and death after hepatectomy: a single institution's experience with 478 consecutive cases. World J Gastroenterol. 2014:20:274-81.

24. Wlodzimirow KA, Eslami S, Abu-Hanna A, Nieuwoudt M, Chamuleau RA. Systematic review: acute liver failure - one disease, more than 40 definitions. Aliment Pharmacol Ther. 2012;35:1245-56.

25. Kristensen MT, Jakobsen TL, Nielsen JW, Jørgensen LM, Nienhuis RJ, Jønsson LR. Cumulated Ambulation Score to evaluate mobility is feasible in geriatric patients and in patients with hip fracture. Dan Med J. 2012;59:A4464.

26. Chung F, Subramanyam R, Liao P, Sasaki E, Shapiro C, Sun Y. High STOPBang score indicates a high probability of obstructive sleep apnoea. Br J Anaesth. 2012;108:768-75.

27. Harris PA, Taylor R, Thielke R, Payne J, Gonzalez N, Conde JG. Research electronic data capture (REDCap) - a metadata-driven methodology and workflow process for providing translational research informatics support. Biomed Inform. 2009:42:377-81.

28. Talab HF, Zabani IA, Abdelrahman HS, Bukhari WL, Mamoun I, Ashour MA, et al. Intraoperative ventilatory strategies for prevention of pulmonary atelectasis in obese patients undergoing laparoscopic bariatric surgery. Anesth Analg. 2009;109:1511-6.

29. Ladha K, Vidal Melo MF, McLean DJ, Wanderer JP, Grabitz SD, Kurth T, et al. Intraoperative protective mechanical ventilation and risk of postoperative respiratory complications: hospital based registry study. BMJ. 2015;351:h3646.

30. Neto AS, Hemmes SN, Barbas CS, Beiderlinden M, Fernandez-Bustamante A, Futier $\mathrm{E}$, et al. Association between driving pressure and development of postoperative pulmonary complications in patients undergoing mechanical ventilation for general anaesthesia: a meta-analysis of individual patient data. Lancet Respir Med. 2016;4:272-80.

31. Acute Respiratory Distress Syndrome Network. Ventilation with lower tidal volumes as compared with traditional tidal volumes for acute lung injury and the acute respiratory distress syndrome. N Engl J Med. 2000; 342:1301-8.

32. Amato MB, Meade MO, Slutsky AS, Brochard L, Costa EL, Schoenfeld DA, et al. Driving pressure and survival in the acute respiratory distress syndrome. N Engl J Med. 2015;372:747-55.

33. Briel M, Meade M, Mercat A, Brower RG, Talmor D, Walter SD, et al. Higher vs lower positive end-expiratory pressure in patients with acute lung injury and acute respiratory distress syndrome: systematic review and meta-analysis. JAMA. 2010;303:865-73.

34. Slutsky AS, Ranieri VM. Ventilator-induced lung injury. N Engl J Med. 2013; 369:2126-36.

35. Serpa Neto A, Simonis FD, Barbas CS, Biehl M, Determann RM, Elmer J, et al. Association between tidal volume size, duration of ventilation, and sedation needs in patients without acute respiratory distress syndrome: an individual patient data meta-analysis. Intensive Care Med. 2014;40:950-7.

36. Neto AS, Simonis FD, Barbas CS, Biehl M, Determann RM, Elmer J, et al. Lung-protective ventilation with low tidal volumes and the occurrence of pulmonary complications in patients without acute respiratory distress syndrome: a systematic review and individual patient data analysis. Crit Care Med. 2015;43:2155-63.

37. Protti A, Cressoni M, Santini A, Langer T, Mietto C, Febres D, et al. Lung stress and strain during mechanical ventilation: any safe threshold? Am J Respir Crit Care Med. 2011;183:1354-62.

38. Samary CS, Santos RS, Santos CL, Felix NS, Bentes M, Barboza T, et al. Biological impact of transpulmonary driving pressure in experimental acute respiratory distress syndrome. Anesthesiology. 2015;123:423-33.

39. Watt DG, Horgan PG, McMillan DC. Routine clinical markers of the magnitude of the systemic inflammatory response after elective operation: a systematic review. Surgery. 2015;157:362-80.

40. Severgnini P, Selmo G, Lanza C, Chiesa A, Frigerio A, Bacuzzi A, et al. Protective mechanical ventilation during general anesthesia for open abdominal surgery improves postoperative pulmonary function. Anesthesiology. 2013;118:1307-21.

41. Futier E, Constantin JM, Paugam-Burtz C, Pascal J, Eurin M, Neuschwander A, et al. A trial of intraoperative low-tidal-volume ventilation in abdominal surgery. N Engl J Med. 2013;369:428-37.

42. Hamlin RJ, Sprung J, Hofer RE, Schroeder DR, Weingarten TN. Obesity trends in the surgical population at a large academic center: a comparison between 1989-1991 to 2006-2008 epochs. Acta Chir Belg. 2013;113:397-400.

43. Bluth T, Pelosi P, de Abreu MG. The obese patient undergoing nonbariatric surgery. Curr Opin Anaesthesiol. 2016;29:421-9.

44. Delay JM, Sebbane M, Jung B, Nocca D, Verzilli D, Pouzeratte Y, et al. The effectiveness of noninvasive positive pressure ventilation to enhance preoxygenation in morbidly obese patients: a randomized controlled study. Anesth Analg. 2008;107:1707-13.

45. Reinius H, Jonsson L, Gustafsson S, Sundbom M, Duvernoy O, Pelosi P, et al. Prevention of atelectasis in morbidly obese patients during general anesthesia and paralysis: a computerized tomography study. Anesthesiology. 2009;111:979-87.

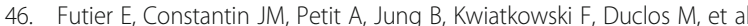
Positive end-expiratory pressure improves end-expiratory lung volume but not oxygenation after induction of anaesthesia. Eur J Anaesthesiol. 2010;27: 508-13.

47. Futier E, Constantin JM, Pelosi P, Chanques G, Massone A, Petit A, et al. Noninvasive ventilation and alveolar recruitment maneuver improve respiratory function during and after intubation of morbidly obese patients: a randomized controlled study. Anesthesiology. 2011;114:1354-63.

48. Pepin JL, Timsit JF, Tamisier R, Borel JC, Levy P, Jaber S. Prevention and care of respiratory failure in obese patients. Lancet Respir Med. 2016;4:407-18.

49. Whalen FX, Gajic O, Thompson GB, Kendrick ML, Que FL, Williams BA, et al. The effects of the alveolar recruitment maneuver and positive end-expiratory pressure on arterial oxygenation during laparoscopic bariatric surgery. Anesth Analg. 2006;102:298-305.

50. Defresne AA, Hans GA, Goffin PJ, Bindelle SP, Amabili PJ, DeRoover AM, et al. Recruitment of lung volume during surgery neither affects the postoperative spirometry nor the risk of hypoxaemia after laparoscopic gastric bypass in morbidly obese patients: a randomized controlled study. Br J Anaesth. 2014;113:501-7. 
51. Hess DR, Kondili D, Burns E, Bittner EA, Schmidt UH. A 5-year observational study of lung-protective ventilation in the operating room: a single-center experience. J Crit Care. 2013;28:533. e9-15.

52. Bender SP, Paganelli WC, Gerety LP, Tharp WG, Shanks AM, Housey M, et al. Intraoperative lung-protective ventilation trends and practice patterns: a report from the Multicenter Perioperative Outcomes Group. Anesth Analg. 2015;121:1231-9.

53. Pelosi P, Ravagnan I, Giurati G, Panigada M, Bottino N, Tredici S, et al. Positive end-expiratory pressure improves respiratory function in obese but not in normal subjects during anesthesia and paralysis. Anesthesiology. 1999:91:1221-31.

54. Eriksen J, Andersen J, Rasmussen JP, Sorensen B. Effects of ventilation with large tidal volumes or positive end-expiratory pressure on cardiorespiratory function in anesthetized obese patients. Acta Anaesthesiol Scand. 1978;22: 241-8.

55. Perilli V, Sollazzi L, Modesti C, Annetta MG, Sacco T, Bocci MG, et al. Comparison of positive end-expiratory pressure with reverse Trendelenburg position in morbidly obese patients undergoing bariatric surgery: effects on hemodynamics and pulmonary gas exchange. Obes Surg. 2003;13:605-9.

56. Albert SP, DiRocco J, Allen GB, Bates JH, Lafollette R, Kubiak BD, et al. The role of time and pressure on alveolar recruitment. J Appl Physiol. 2009;106: 757-65.

\section{Submit your next manuscript to BioMed Central} and we will help you at every step:

- We accept pre-submission inquiries

- Our selector tool helps you to find the most relevant journal

- We provide round the clock customer support

- Convenient online submission

- Thorough peer review

- Inclusion in PubMed and all major indexing services

- Maximum visibility for your research

Submit your manuscript at www.biomedcentral.com/submit 